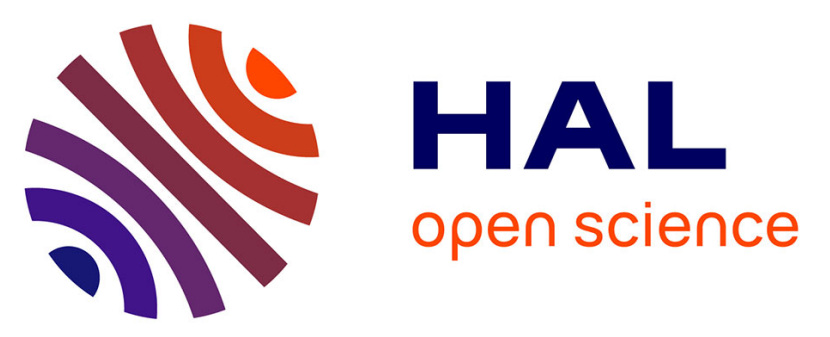

\title{
An Overview of the 2013 Las Vegas Ozone Study (LVOS): Impact of stratospheric intrusions and long-range transport on surface air quality
}

A.O. Langford, C.J. Senff, Alvarez R.J., Jérôme Brioude, O.R. Cooper, J.S. Holloway, M. Lin, R.D. Marchbanks, R.B. Pierce, S.P. Sandberg, et al.

\section{To cite this version:}

A.O. Langford, C.J. Senff, Alvarez R.J., Jérôme Brioude, O.R. Cooper, et al.. An Overview of the 2013 Las Vegas Ozone Study (LVOS): Impact of stratospheric intrusions and long-range transport on surface air quality. Atmospheric environment, 2014, pp.1-18. 10.1016/j.atmosenv.2014.08.040 . hal-01070002

\section{HAL Id: hal-01070002 https://hal.science/hal-01070002}

Submitted on 30 Sep 2014

HAL is a multi-disciplinary open access archive for the deposit and dissemination of scientific research documents, whether they are published or not. The documents may come from teaching and research institutions in France or abroad, or from public or private research centers.
L'archive ouverte pluridisciplinaire HAL, est destinée au dépôt et à la diffusion de documents scientifiques de niveau recherche, publiés ou non, émanant des établissements d'enseignement et de recherche français ou étrangers, des laboratoires publics ou privés. 

stratospheric intrusions and long-range transport on surface air quality Holloway $^{1,2}$, M.Y. Lin ${ }^{4,5}$, R.D. Marchbanks ${ }^{1,2}$, R.B. Pierce ${ }^{6}$, S.P. Sandberg ${ }^{1}$, A.M. Weickmann $^{1,2}$, and E.J. Williams ${ }^{1}$

$8{ }^{1}$ NOAA Earth System Research Laboratory/Chemical Sciences Division, Boulder, 9 Colorado 80305 USA.

${ }^{2}$ Cooperative Institute for Research in the Environmental Sciences, University of

$14{ }^{3}$ Laboratoire de l'Atmosphere et des Cyclones (LACy), UMR 8105, Saint-Denis, La 15 Reunion, France.

$17{ }^{4}$ Atmospheric and Oceanic Sciences, Princeton University, Princeton, 18 New Jersey, USA. 
1 Abstract. The 2013 Las Vegas Ozone Study (LVOS) was conducted in the late spring

2 and early summer of 2013 to assess the seasonal contribution of stratosphere-to-

3 troposphere transport (STT) and long-range transport to surface ozone in Clark County,

4 Nevada and determine if these processes directly contribute to exceedances of the

5 National Ambient Air Quality Standard (NAAQS) in this area. Secondary goals included

6 the characterization of local ozone production, regional transport from the Los Angeles

7 Basin, and impacts from wildfires. The LVOS measurement campaign took place at a

8 former U.S. Air Force radar station $\sim 45 \mathrm{~km}$ northwest of Las Vegas on Angel Peak $(\sim 2.7$

9 km above mean sea level, asl) in the Spring Mountains. The study consisted of two

10 extended periods (May 19 - June 4 and June 22 - 28, 2013) with near daily 5-minute

11 averaged lidar measurements of ozone and backscatter profiles from the surface to $\sim 2.5$

$12 \mathrm{~km}$ above ground level ( 5.2 km asl), and continuous in situ measurements (May 20 -

13 June 28) of $\mathrm{O}_{3}, \mathrm{CO},(1-\mathrm{min})$ and meteorological parameters (5-min) at the surface. These

14 activities were guided by forecasts and analyses from the FLEXPART particle dispersion

15 model and the Real Time Air Quality Modeling System (RAQMS), and the GFDL AM3

16 chemistry-climate model. In this paper, we describe the LVOS measurements and

17 present an overview of the results. The combined measurements and model analyses

18 show that STT directly contributed to each of the three exceedances that occurred in

19 Clark County during LVOS, with contributions to 8-h surface ozone in excess of $30 \mathrm{ppbv}$

20 on each of these days. Our analyses also shows that ozone exceedances would have

21 occurred at a rate greater than $50 \%$ if the 8 -h ozone NAAQS had been 65 ppbv instead of

$2275 \mathrm{ppbv}$, making these springtime events the rule rather than the exception. 


\section{Introduction}

2 Surface ozone $\left(\mathrm{O}_{3}\right)$ has decreased dramatically across much of the eastern United

3 States over the last two decades [He et al., 2013; Lefohn et al., 2010], largely as a result

4 of stricter emission controls on stationary and mobile $\mathrm{NO}_{\mathrm{x}}$ sources [Butler et al., 2011;

$5 E P A, 2012]$. More than $65 \%$ of the rural eastern U.S. sites surveyed in a recent study by

6 Cooper et al. [2012] showed statistically significant decreases in median ozone during the

7 summer with $43 \%$ also exhibiting significant decreases in the spring. In contrast, only

$88 \%$ of the western U.S. rural sites examined showed similar summertime decreases, and

9 more than $50 \%$ had significant springtime increases. These east-west differences have

10 been partially attributed to increasing emissions of $\mathrm{NO}_{\mathrm{x}}$ and other ozone precursors from

11 industrial activities and development in East Asia [Brown-Steiner and Hess, 2011; Jacob

12 et al., 1999; Zhang et al., 2011] and to a higher fraction of background ozone in the

13 western U.S. due to stratospheric influence [Lin et al., 2012a]

14 Much of the pollution emitted in East Asia is carried eastward across the North

15 Pacific Ocean by the prevailing winds. The fastest transport occurs in the mid-and upper

16 troposphere, often associated with Asian boundary layer pollution being entrained into

17 the warm conveyer belts (WCB) of midlatitude cyclones, and these plumes can descend

18 to the surface of western North America [Brown-Steiner and Hess, 2011; Cooper et al.,

19 2004b; Liang et al., 2005; Lin et al., 2012b; Stohl, 2001]. The high average elevation and

20 deep boundary layers of the intermountain west increase the likelihood that some of this

21 pollution may reach the surface as the plumes move inland and the transported pollution

22 descends isentropically behind cold fronts [Liang et al., 2004]. Asian pollution can also

23 be transported to western North America at low altitude but only has a significant impact 
1 in summer [Holzer and Hall, 2007].

2 Stratosphere-to-troposphere transport (STT) also contributes to the relatively high

3 background ozone in boundary layer air transported ashore from the north Pacific during

4 spring and can likewise lead to episodic increases at the surface [Ambrose et al., 2011;

5 A.O. Langford et al., 2009; Lefohn et al., 2011]. Direct transport of undiluted

6 stratospheric air to the surface is uncommon, but some exchange of air between the upper

7 troposphere and lower stratosphere occurs with all midlatitude cyclones [Johnson and

8 Viezee, 1981] and a fraction of the ozone-rich air descending in the dry airstream (DA)

9 may be entrained into the deep springtime boundary layers of the intermountain west.

10 This descending air can also become interleaved with long-range transport layers in the

11 WCB [Cooper et al., 2004a; Cooper et al., 2004b; Stohl and Trickl, 1999].

12 Several climatologies [James et al., 2003; Sprenger and Wernli, 2003; Wernli and

13 Bourqui, 2002] suggest that deep stratospheric intrusions (i.e. those penetrating to within

$14 \sim 3 \mathrm{~km}$ of the surface) are most likely to form near the exit of the east Pacific storm track

15 above the Pacific Northwest with the deepest descent of stratospheric air near the coast of

16 Southern California. These conclusions are consistent with measurements [A. $O$.

17 Langford et al., 2012] made during the 2010 California Research at the Nexus of Air

18 Quality and Climate Change (CalNex) field study, and with analyses from the

19 NOAA/GFDL AM3 global-high resolution $(\sim 50$ x $50 \mathrm{~km})$ chemistry-climate model.

20 Figure 1 displays the mean contributions of (a) STT [Lin et al., 2012a], and (b) transport

21 from Asia [Lin et al., 2012b] to the daily maximum 8-h average (MDA8) surface $\mathrm{O}_{3}$ in

22 the United States during May and June of 2010. These plots show the greatest impact of

23 both transport processes to be in the Intermountain West with minimal contributions 
1 along the Gulf Coast and in the Southeastern U.S.. The striking similarity between the

2 two plots reflects the primary role of midlatitude cyclones in both transport processes.

3 The AM3 model shows the stratospheric contribution to surface ozone during May and

4 June of 2010 to be roughly 3 times that of long-range transport.

5 Since the higher background concentrations and episodic increases associated with

6 STT and Asian pollution are unaffected by local control strategies, these processes pose a

7 serious challenge for air quality managers tasked with meeting the National Ambient Air

8 Quality Standard (NAAQS) in the western United States. This is especially true in late

9 spring when the contribution from local and regional photochemistry is also rapidly

10 increasing. The problem will be compounded if the NAAQS is reduced from the current

11 (2008) value of 75 parts-per-billion by volume (ppbv) for the MDA8

12 (http://www.epa.gov/oaqps001/greenbk/hindex.html). Although the U.S. EPA has

13 established a provision (http://www.epa.gov/ttn/analysis/exevents.htm) to identify and

14 exclude these "exceptional events", the shrinking margin between the NAAQS and

15 increasing springtime background concentrations means that even modest episodic

16 additions of 5 to $10 \mathrm{ppbv}$ from STT or Asian pollution can potentially lead to

17 exceedances of the NAAQS. Exceedance events will become increasingly frequent if the

18 NAAQS is decreased to 70 ppbv or less, and the "exceptional events" approach may no

19 longer be viable.

20 Concern about this problem and its implications for air quality management in Clark

21 County, NV provided the motivation for the Las Vegas Ozone Study (LVOS) conducted

22 in May and June of 2013. The primary goal of LVOS was to assess the seasonal

23 contribution of stratosphere-to-troposphere transport (STT) and long-range transport to 
1 surface ozone in Clark County and to determine the magnitude of the direct contribution

2 of these processes to exceedances of the National Ambient Air Quality Standard

3 (NAAQS) in this area. Secondary goals included the characterization of local ozone

4 production, regional transport from the Los Angeles Basin, and impacts from wildfires.

5 The study was funded by the Clark County Department of Air Quality (CC/DAQ) and

6 conducted by the NOAA Earth System Research Laboratory Chemical Sciences Division

7 (ESRL/CSD). In this paper, we present an overview of the LVOS campaign and

8 summarize the major findings and implications for air quality management in the western

9 United States.

\section{2. Background}

12 Clark County, Nevada (Figure 2) is home to the Las Vegas-Henderson-Paradise, NV

13 Metropolitan Statistical Area (MSA), one of the fastest growing areas in the United States.

14 The population of this MSA, which includes the cities of Las Vegas, Henderson, North

15 Las Vegas, Boulder City, and Paradise, was slightly under 2 million in the 2010 U.S.

16 Census or more than $70 \%$ of the total population of Nevada. Nearly 40 million more

17 people visit Las Vegas each year (http://www.lvcva.com/stats-and-facts/) and the 2011

18 National Emissions Inventory (http://www.epa.gov/ttn/chief/net/2011inventory.html)

19 estimates that about $75 \%$ of the $\mathrm{NO}_{\mathrm{x}}$ and $5 \%$ of the VOCs emitted in Clark County are

20 derived from mobile sources. More than $90 \%$ of the emitted VOCs are derived from

21 biogenic sources and about half of the remaining $\mathrm{NO}_{\mathrm{x}}$ comes from one coal-fueled, and

22 five natural gas-fueled power plants that provide about $5 \mathrm{MW}$ of electricity for the area.

23 Most of the population and development is confined to the Las Vegas Valley (LVV), a 
$1 \quad 1600 \mathrm{~km}^{2}$ basin that lies between 500 and $900 \mathrm{~m}$ above mean sea level (asl) and is

2 bounded on the west by the Spring Mountains and to the north by the Sheep Mountains,

3 with the Muddy Mountains to the east and Black Mountains to the south. The I-15

4 corridor through the Mojave Desert and Cajon Pass links Las Vegas with the eastern Los

5 Angeles Basin about $275 \mathrm{~km}$ to the southwest. The Cajon Pass and I-15 corridor is also a

6 potential pathway for export of pollution from the Los Angeles Basin into the Mojave

7 Desert and the Las Vegas Valley.

8 The Clark County Department of Air Quality maintains a network of continuous

9 ambient monitoring stations (CAMS) that measure surface ozone along with

10 meteorological parameters and other trace gases (cf. Figure 2b). Figure 3 plots the

11 average MDA8 ozone measured at the monitoring station in Jean over the 3-yr period

12 from 2010 to 2012. Jean is located along the I-15 corridor in the Mojave Desert about 45

$13 \mathrm{~km}$ southwest of downtown Las Vegas at an elevation of $924 \mathrm{~m}$ asl. Since Jean is usually

14 upwind of Las Vegas, but downwind of Los Angeles, it is the Clark County monitor least

15 affected by local emissions, but most sensitive to transport from Southern California.

16 Figure 3 also plots the corresponding time series from five monitors operated by the U.S.

17 National Parks Service [2013] at remote locations surrounding Clark County (open

18 circles in Figure 2a). The ozone seasonal cycle and the synoptic scale variability is very

19 similar at all six sites with the highest concentrations in May and June or nearly two

20 months before the maximum surface temperatures and greatest photochemical production.

21 This suggests that it is primarily large-scale transport that determines the mean ozone at

22 all six sites, although the influence of the LA Basin is seen in the slightly higher (1 to 4

23 ppbv) average concentrations at the Mojave National Reserve and at Jean during May 
1 and June. The sudden drop in ozone at all six sites in early July reflects the shift in the

2 prevailing winds from southwesterly to southerly when the North American summer

3 monsoon develops and the background concentrations are no longer determined by

4 inflow from the Pacific.

5 Although Clark County is currently in attainment of the NAAQS (i.e. the 3-year

6 average of the annual 4th highest measured MDA8 ozone concentration did not exceed

$7 \quad 0.075$ ppmv, parts-per-million by volume) based on data acquired between 2009 and

8 2011, the standard will be exceeded when more recent measurement periods are

9 considered. The 3-year average (2010-2012) of the fourth highest MDA8 concentration

10 was $0.075 \mathrm{ppmv}$ or $75 \mathrm{ppbv}$ at Jean, and $77 \mathrm{ppbv}$ at Joe Neal, the northernmost monitor

11 in the Las Vegas Valley (cf. Figure 2b). When the 2011-2013 data are used, the fourth

12 highest value will still be 75 ppbv at Jean, but Joe Neal, Palo Verde, and two other Clark

13 County monitors will be in exceedance.

\section{3. LVOS Measurement Campaign}

16 The LVOS measurement campaign was conducted between May 19 and June 28,

172013 at a former U.S. Air Force General Surveillance Radar station atop Angel Peak

$18\left(36.32{ }^{\circ} \mathrm{N}, 115.57^{\circ} \mathrm{W}, 2,682 \mathrm{~m}\right.$ asl) (Figure 4) about $45 \mathrm{~km}$ northwest of Las Vegas in

19 the Spring Mountains and Toiyabe National Forest. The summit overlooks the Kyle

20 Canyon drainage and the primary access road to the Las Vegas Valley to the southeast.

21 The radar station was decommissioned by the Air Force in 1969 and the property

22 transferred to the Department of the Interior and to Clark County with the remaining

23 operational radar system transferred to the Federal Aviation Administration (FAA). This 
1 limited-access site currently serves as a communications relay facility for Clark County

2 and other state and federal agencies. The former cantonment area below the summit of

3 Angel Peak was transferred to Clark County for operation as the Spring Mountain Youth

4 Camp (SMYC). Angel Peak is relatively isolated from major emission sources and is

5 usually exposed to free tropospheric air during the night. However, the site is frequently

6 subjected to air from the Las Vegas Valley during late spring and summer when

7 thermally driven upslope flows develop during the day and the mixed layer above the

8 valley floor can grow to more than $4 \mathrm{~km}$ deep.

9 The weather was mostly mild and dry with clear skies or scattered fair weather

10 cumulus during the field campaign. The overall seasonal upward trend in temperature

11 (Figure 5a) was punctuated by the passage of several cold fronts associated with deep

12 upper level troughs or closed lows moving through the Pacific Northwest. The passage

13 of these troughs is seen in both the Angel Peak surface pressure and in the NCEP/CDAS

14 Reanalysis $500 \mathrm{hPa}$ geopotential heights averaged over a $5^{\circ} \times 5^{\circ}$ box centered at $36^{\circ} \mathrm{N}$,

$15115^{\circ} \mathrm{W}$ (Figure 5b). Strong SSW winds usually accompanied these systems (Figure 5c),

16 and the descending air behind the fronts led to two extended periods (May 21-26, and

17 June 13-18) with much drier air at the surface (Figure 5a). There were also two periods

18 (June 4-9 and June 26-29) with strong ridging, warmer temperatures, and weak winds

19 that led to regional stagnation and build up of $\mathrm{O}_{3}$ from local photochemical production.

20 These periods were accompanied by strong upslope flow at Angel Peak and afternoon

21 fair weather cumulus (cf. Figure 5a). More extensive cloud cover occurred on May 21

22 and June 25. The yellow bars highlight the three days (May 21, 25, and June 21) when 
1 the $75 \mathrm{ppbv} 2008 \mathrm{O}_{3} \mathrm{NAAQS}$ was exceeded by one or more of the regulatory monitors in

2 the Las Vegas Valley.

$4 \quad 3.1$ TOPAZ lidar measurements

5 The primary instrument used during LVOS was the TOPAZ (Tunable optical profiler

6 for aerosols and ozone) 3-wavelength mobile differential absorption lidar (DIAL) system,

7 which can profile ozone and aerosol layers from near the surface to $\sim 2.5 \mathrm{~km}$ above

8 ground level (agl). TOPAZ was reconfigured from the nadir-viewing aircraft-based

9 version described previously [Alvarez II et al., 2011; A. O. Langford et al., 2010] and

10 installed in the back of a truck for ground-based operations after the CalNex field

11 campaign. The lidar is oriented in a zenith-viewing configuration with a large motorized

12 vertically scanning mirror on top of the truck to permit line of sight measurements along

13 elevation angles ranging from $-6^{\circ}$ (i.e. below the horizon) to $30^{\circ}$ at a fixed azimuth

14 direction. The mirror can also be moved completely out of the light path for zenith

15 measurements. The truck was parked on the south edge of the Angel Peak summit and

16 the azimuth angle fixed at $130^{\circ}$ to overlook the Kyle Canyon drainage (Figure $4 \mathrm{~b}$, filled

17 square).

18 TOPAZ uses near and far field detection channels to extend the dynamic range and

19 can profile ozone over distances from about $400 \mathrm{~m}$ to $2.5 \mathrm{~km}$ during the day with the

20 limits determined by the point of full overlap between the transmitter and receiver in the

21 near field and the useful signal-to-noise cut off in the far field. The DIAL profiles are

22 analyzed using a range resolution of $90 \mathrm{~m}$, and a 450-m running average to smooth the

23 resulting profiles. In normal operation, the scanning mirror is stepped through a series of 
1 angles to allow viewing at elevations of $2,6,20$, and $90^{\circ}$ above the horizon in a 5-min

2 cycle with the backscatter returns averaged for $75 \mathrm{~s}$ at each angle. The resulting slant

3 angle profiles are then projected along the zenith to create continuous vertical profiles

4 down to about $15 \mathrm{~m}$ above the ground. The effective horizontal footprint of these

5 blended profiles increases from about 11 meters near the top of the profile to about $900 \mathrm{~m}$

6 near the surface. For comparison, the horizontal sampling footprint associated with the

$775 \mathrm{~s}$ integration time ranged from about 150 to $750 \mathrm{~m}$ for typical background winds of 2

8 to $10 \mathrm{~m} / \mathrm{s}$.

9 TOPAZ is partially automated, but does not run autonomously and requires 1 to 2

10 operators. Each LVOS observing session consisted of 2 to 20 hours of nearly continuous

115 -minute averaged ozone and backscatter profiles from the surface to $\sim 2.5 \mathrm{~km}$ above

12 ground level $(\sim 5.2 \mathrm{~km}$ above mean sea level). The system operated on 25 out of 43

13 possible days during LVOS, with a laser failure in mid-June dividing the data record into

14 two intensive periods: May 19 to June 4, and June 22 to 28 . Figure 6 displays a series of

15 time-height color curtain plots showing the ozone concentrations measured by the

16 TOPAZ lidar. The superimposed solid black traces show the normalized integrated

17 backscatter from $\sim 15 \mathrm{~m} \mathrm{agl}$ to $2000 \mathrm{~m}$ agl (relative to the summit of Angel Peak) and the

18 dotted gray lines the normalized solar radiation from the SMYC. The " $\mathrm{x}$ " symbols

19 represent the afternoon mixed layer depth determined from the 0000 UT (1700 Pacific

20 Daylight Time, PDT) McCarran International Airport (VEF) soundings; “+” symbols are

21 plotted when the mixed layer was deeper than $5 \mathrm{~km}$ asl and " 0 " is plotted when the

22 sounding is missing. The top of the afternoon mixed layer was always at least as high as

23 the summit of Angel Peak. The most striking features of these plots are the frequent 
1 layers with more than 100 ppbv of $\mathrm{O}_{3}$ detected within a few $\mathrm{km}$ of the Angel Peak

2 summit in late May. These layers were observed only under clear sky conditions and the

3 backscatter profiles (not shown) indicate very low aerosol loadings associated with these

4 layers consistent with a UT/LS origin. The McCarran soundings show that many of these

5 filaments descended low enough to interact with the deep afternoon mixed layers. Note

6 that these layered structures are qualitatively different from the deep column of elevated

$7 \mathrm{O}_{3}$ and very high backscatter observed on June 2 when the plume from the 28,000 acre

8 Powerhouse Fire burning near Los Angeles engulfed Angel Peak. Another interesting

9 feature of Figure 6 is the unusually low $\mathrm{O}_{3}$ concentrations with relatively low backscatter

10 seen extending well above Angel Peak on June 24-26. These low concentrations reflect a

11 deep incursion of subtropical marine boundary layer air transported over the western U.S.

12 by the counterclockwise circulation around an unusually large cyclone sitting over the

13 Gulf of Alaska. More detailed descriptions of these various events will be presented

14 elsewhere.

\section{$16 \quad 3.2$ In situ measurements}

17 Surface $\mathrm{O}_{3}$ and $\mathrm{CO}$ concentrations were measured continuously at Angel Peak from

18 May 20 to June 29. Ozone concentrations were determined using a commercial UV-

19 absorbance monitor with a detection limit of $1 \mathrm{ppbv}$ for a 1-min integration time and an

20 uncertainty of $2 \%$ [Williams et al., 2006]. This instrument was calibrated against a

21 reference standard in the laboratory prior to deployment. Carbon monoxide was

22 measured using a modified commercial vacuum ultraviolet fluorescence [Holloway et al.,

232000 ] monitor with a detection limit below $1 \mathrm{ppbv}$ for a 1-min integration time and an 
1 accuracy of $4 \%$. This instrument was zeroed and calibrated hourly against a reference

2 standard. Both instruments were installed within a temperature-regulated room in the

3 former radar building nearest TOPAZ (cf. Figure 4b, filled triangle), and sampled air at 1

4 standard liter per minute through $6 \mathrm{~mm}$ diameter and $30 \mathrm{~m}$ long PFA

5 (polytetrafluoroethylene) lines. The inlets were equipped with $47 \mathrm{~mm}$ TFE

6 (tetrafluroethylene) particulate filters and mounted $\sim 2 \mathrm{~m}$ above the building roof or about

$712 \mathrm{~m}$ above ground level (agl). Data from periods influenced by $\mathrm{NO}_{\mathrm{x}}$ and $\mathrm{CO}$ emissions

8 from vehicles, backup generator testing, and other local activities were identified and

9 removed from the records.

10 Figure 7a plots the continuous 1-min in situ surface $\mathrm{O}_{3}$ measurements from Angel

11 Peak (blue line) together with the 15 to $2000 \mathrm{~m}$ agl average $\mathrm{O}_{3}$ from TOPAZ (red

12 symbols). The corresponding $\mathrm{CO}$ measurements are plotted in Figure 7b. The 8-h $\mathrm{O}_{3}$

13 NAAQS was exceeded at Angel Peak on seven days during LVOS (May 24, 25, 30 and

14 June 2, 17, 18). Background CO peaks in the springtime [Kim et al., 2008] and the

15 concentrations at Angel Peak accordingly declined slowly over the course of the

16 campaign. The only large increases in $\mathrm{CO}$ beyond the daily 20 to $30 \mathrm{ppbv}$ variations

17 associated with the diurnal upslope flow coincided with the arrival of the Powerhouse

18 Fire plume on June 2 when the concentrations nearly doubled, and on June 27 when

19 polluted air from the Las Vegas Valley was transported to Angel Peak by strong upslope

20 flow. The characteristics of the fire plume on June 2 contrast sharply with the relatively

21 low $\mathrm{CO}$ and aerosol backscatter (cf. Figure 6) measured during the late May exceedance

22 days. The concentrations of $\mathrm{O}_{3}$ and $\mathrm{CO}$ decreased to as low as 22 and 69 ppbv,

23 respectively, in the subtropical marine boundary layer air on June 24-26. 
Surface $\mathrm{O}_{3}$ and $\mathrm{CO}$ averaged $62 \pm 8$ and $116 \pm 15$ ppbv over the first 5 weeks of the

2 campaign (May 19 to June 23). These values are similar to the free tropospheric

3 concentrations measured by the CalNex WP-3D flights above the Los Angeles Basin

4 during May of 2010 [Neuman et al., 2011]. The overall average concentrations from

5 those flights were 66 and $120 \mathrm{ppbv}$ for $\mathrm{O}_{3}$ and $\mathrm{CO}$, respectively, with mean values of

$6 \quad 71 \pm 8$ and $108 \pm 6$ ppbv for air of upper tropospheric origin, $53 \pm 10$ and $106 \pm 10$ ppbv for

7 air from the marine boundary layer, $69 \pm 6$ and $136 \pm 10$ ppbv for Asian transport plumes,

8 and $65 \pm 4$ and $134 \pm 7$ ppbv for aged regional emissions based on FLEXPART back

9 trajectories. The MDA8 $\mathrm{O}_{3}$ at Angel Peak on the three Clark County exceedance days

10 was $70 \pm 3,78 \pm 1$, and $77 \pm 3$ ppbv, respectively, with corresponding CO concentrations of

$11115 \pm 6,111 \pm 6$, and $121 \pm 6$ ppbv. The low CO concentrations and aerosol backscatter on

12 the first two exceedance days indicate a strong upper troposphere/lower stratosphere

13 (UT/LS) influence; the higher concentrations during the third episode are consistent with

14 an additional contribution from Asian pollution.

15 The $\mathrm{O}_{3}$ concentrations measured aloft by TOPAZ were generally higher than those

16 measured at the summit of Angel Peak in late May when there were frequent upper level

17 cyclones, but lower in mid and late June when the strong high-pressure ridges developed.

18 This shows that the surface concentrations at Angel Peak were influenced primarily by

19 descending air in the first instances, and by upslope flow from the valley during the

20 stagnation episodes. The simultaneous operation of TOPAZ with its horizontal viewing

21 capabilities and the in situ $\mathrm{O}_{3}$ monitor allowed regular comparisons between the two

22 measurement techniques. Figure 8 plots the TOPAZ $\mathrm{O}_{3}$ measurements made at several

23 altitudes against the in situ measurements from Angel Peak. The red crosses represent all 
1 of the coincident measurements and the filled black circles those measurements acquired

2 between 1400 and 1600 PDT on days (18 out of 25) when the afternoon (0000 UT or

31700 PDT) soundings at McCarran Airport showed the top of the mixed layer to be at

4 least $2000 \mathrm{~m}$ higher than the summit of Angel Peak (i.e. $>4.7 \mathrm{~km}$ asl). The black and red

5 solid lines show the corresponding linear regression fits. The air above Angel Peak was

6 generally too clean to allow direct determination of the local mixed layer height from

7 aerosol gradients [White et al., 1999]. Figure 8a shows excellent agreement between the

8 in situ measurements and the lowest TOPAZ measurements despite the spatial

9 differences; the first TOPAZ bin averages the concentrations over a $2^{\circ}$ slant path ranging

10 from 400 to $1400 \mathrm{~m}$ distant from the inlets horizontally, and from $\sim 15$ to $50 \mathrm{~m}$ above the

11 summit, or 200 to $400 \mathrm{~m}$ above the southeastern flank of Angel Peak. The measurements

12 agree to within $3 \%$ with a high degree of correlation $\left(\mathrm{R}^{2}=0.930\right)$. The correlation is

13 improved $\left(\mathrm{R}^{2}=0.967\right)$, but the agreement slightly degraded $(5 \%)$ when only data

14 acquired when the McCarran soundings showed the boundary layer to be deep and well

15 mixed is used. Not surprisingly, the agreement becomes worse when the TOPAZ

16 concentrations from (b) $500 \mathrm{~m}$, (c) $1000 \mathrm{~m}$, or (d) 15 to $2000 \mathrm{~m}$ agl are compared to the

17 in situ measurements. The measurement precision should be very similar in Figures 8a

18 and $8 \mathrm{c}$ since both sets of data were acquired at a range of $\sim 1000 \mathrm{~m}$ from the lidar (at

19 beam elevations of $2^{\circ}$ and $90^{\circ}$, respectively) and the increased scatter at higher altitudes

20 is almost entirely due to atmospheric variability and the frequent presence of high $\mathrm{O}_{3}$

21 layers aloft. The differences between the two measurements under well-mixed conditions

22 are well within the combined uncertainties and much smaller than the observed altitude

23 dependences. 
$2 \quad 3.3$ Supporting measurements

3 The Angel Peak chemical measurements were complemented by a GPS-enabled

4 weather station that recorded continuous 5-min averaged winds, temperature, and relative

5 humidity from a 3 m mast located near the southeastern edge of Angel Peak (cf. Figure

$64 \mathrm{~b}$, filled circle). This position provided unobstructed fetch for wind directions between

745 and $270^{\circ}$, which occurred more than $75 \%$ of the time during the study. However, the

8 anemometer was partially sheltered by the TOPAZ truck to the northwest and the former

9 radome building housing the in situ instruments to the north. Additional meteorological

10 data and solar irradiance were obtained from the Western Regional Climate Center

11 (WRCC) weather station (www.wrcc.dri.edu/weather/smyc.html) situated about $125 \mathrm{~m}$

12 lower in elevation and $800 \mathrm{~m}$ to the west of the summit at the SMYC.

13 The routine measurements from the Clark County DAQ network of continuous

14 ambient monitoring sites (CAMS) provide additional points of comparison for the Angel

15 Peak ozone measurements. Figure 4a shows the 7 CAMS that were operational in the

16 Las Vegas Valley (Joe Neal, Palo Verde, J.D. Smith, Walter Johnson, Jerome Mack, Paul

17 Meyer, and Winterwood) during LVOS, with the 4 sites located in outlying areas (Jean,

18 Boulder City, Apex, and Mesquite) shown in Figure 2b. Clark County provided 5-min

19 average $\mathrm{O}_{3}$ data for the duration of the LVOS campaign in addition to the standard hourly

20 and MDA8 data available online (www.ccaqapps5m.co.clark.nv.us). Many of the CAMS

21 also measured meteorological parameters, particulates, or other chemical species in

22 addition to ozone. The U.S. National Park Service also provided $\mathrm{O}_{3}$ measurements with

23 1-min integration times from Great Basin and Death Valley, (cf. Figure 2a), and 1-h 
1 measurements from other locations were obtained from the U.S. EPA AirNow

2 (www.airnowtech.org) or California Air Resources Board (www.arb.ca.gov) online

3 databases. The vertical structure of the atmosphere was profiled hourly by an upper-air

4 monitoring station comprised of a radar wind profiler, sodar, and profiling radiometer

5 maintained by the DAQ at the North Las Vegas Airport (VGT), and by the twice daily

6 (0500 and 1700 PDT) radiosondes launched by the National Weather Service (NWS)

7 from the McCarran International Airport (VEF) (cf. Figure 4a). The horizontal

8 distribution of clouds, smoke plumes, and mid-tropospheric water vapor was obtained

9 from hourly GOES-WEST $1 \mathrm{~km}$ visible, $4 \mathrm{~km}$ infrared, and $8 \mathrm{~km}$ water vapor imagery,

10 and from the NASA MODIS products.

11 Figure 9 plots the continuous 1-min in situ surface $\mathrm{O}_{3}$ measurements from Angel

12 Peak (black) together with the 5-min measurements from the Clark County monitoring

13 stations at Joe Neal (blue), Jean (green), and Apex (purple) (cf. Figure 4). The 15 to

$142000 \mathrm{~m}$ agl TOPAZ measurements are plotted in red. Joe Neal lies to the north of Las

15 Vegas and about $30 \mathrm{~km}$ ESE of Angel Peak near the mouth of the Kyle Canyon drainage,

16 which links Angel Peak to the Las Vegas Valley. This site typically measures some of

17 the highest $\mathrm{O}_{3}$ concentrations in the LVV. Apex is situated in a rural area north of Las

18 Vegas and on the far side of the valley about $61 \mathrm{~km}$ ENE of Angel Peak and Jean is

19 located in the Mojave Desert about $65 \mathrm{~km}$ to the SSW (cf. Section 2). Whereas surface

$20 \mathrm{O}_{3}$ exhibits little diurnal variation at Angel Peak, the concentrations at all of these lower-

21 lying sites often decrease during the late night and early morning as $\mathrm{O}_{3}$ is destroyed by

22 surface deposition or titration beneath the shallow inversions that form when the winds

23 are calm. The five data series converge at other times, however, including the afternoons 
1 and evenings of May 21, May 25, and June 21 when the Clark County exceedances

2 occurred. The correlation coefficients from scatter plots similar to those in Figure 8, but

3 comparing the afternoon (1400 to 1600 PDT) Angel Peak ozone measurements to those

4 made by the CC/DAQ monitors in the valley range from $\mathrm{R}^{2}=0.645$ for Palo Verde, which

5 lies on the western side of the valley and is the nearest monitor to Angel Peak, to

$6 \quad \mathrm{R}^{2}=0.541$ at Jerome Mack, which is located near the eastern side of the valley and

7 downtown Las Vegas. The correlation coefficients for Joe Neal and Jean are $\mathrm{R}^{2}=0.645$

8 and $\mathrm{R}^{2}=0.565$, respectively. As noted above, the $\mathrm{O}_{3}$ concentrations measured on or above

9 Angel Peak were generally higher than those in the valley following cold fronts (e.g. May

$10 \quad 20-21$ and 24-25), but were usually lower than or comparable to the concentrations in the

11 northern valley during strong ridging (e.g. June 4-8 and June 27-28).

12 The regional nature of the high $\mathrm{O}_{3}$ episodes in Clark County during LVOS is

13 apparent from Figure 10, which compares the surface measurements from Jean and

14 Angel Peak plotted in Figure 9 to the 5-min $\mathrm{O}_{3}$ measurements from the U.S. National

15 Parks Service monitors at Death Valley and Great Basin National Parks (cf. Figure 2a).

16 Ozone was relatively high in Death Valley NP on the evening of May 21 and was also

17 elevated at Great Basin NP later that night. Ozone was also elevated on the night of May

1824 at Death Valley NP and at all four sites on May 25. There was another short-lived

19 ozone peak on the afternoon of June 2 at Death Valley NP associated with the

20 Powerhouse Fire followed by an increase later in the evening at Great Basin NP. Great

21 Basin National Park reported only three exceedances of the NAAQS in all of 2013 with

22 the MDA8 reaching 76 ppbv on May 5 (see below), May 25, and June 18. Although

23 there were no exceedances of the NAAQS in Death Valley National Park during 2013, 
1 the two highest ozone days of the year were May 24 and 25 where the MDA8 $\mathrm{O}_{3}$ reached

274 and 73 ppbv, respectively.

4 4. Model Analyses

The NOAA/NESDIS RAQMS and NOAA/ESRL/CSD FLEXPART models were

6 used to forecast STT and long-range transport events during the LVOS measurement

7 campaign with supplemental analyses from the NOAA/ESRL/GSD Rapid Refresh Air

8 Quality Model (http://ruc.noaa.gov/wrf/WG11_RT/Welcome.cgi) that uses RAQMS

9 lateral boundary conditions. The NOAA GFDL AM3 and FLEXPART models were then

10 used to estimate the contribution of STT and long range transport to surface ozone in the

11 western U.S. and to Clark County following the field campaign.

$13 \quad$ 4.1 RAQMS

14 RAQMS (Realtime Air Quality Modeling System) is a unified (stratosphere-

15 troposphere) online global chemical and aerosol assimilation/forecasting system that has

16 been used to support several airborne field missions [Pierce et al., 2003; Pierce et al.,

17 2007]. Forecasts were initialized daily at 1200 UT with real-time assimilation of OMI

18 cloud-cleared total column ozone and MLS ozone profiles from the NASA Aura satellite,

19 and MODIS aerosol optical depth from the NASA Terra and Aqua satellites. The $\mathrm{O}_{3}$ and

$20 \mathrm{CO}$ distributions over the North Pacific $\left(10\right.$ to $72^{\circ} \mathrm{N},-110$ to $\left.-50^{\circ} \mathrm{E}\right)$ were predicted at 6-

21 hour intervals for the next 4 days. RAQMS has been run routinely since 2010 with $2^{\circ} \mathrm{x}$

$222^{\circ}$ resolution analyses and forecasts prior to 2012 , and $1^{\circ} \times 1^{\circ}$ resolution after 2012.

23 RAQMS plots are archived online (http://raqms-ops.ssec.wisc.edu). Figure 11 displays 
1 the RAQMS $1^{\circ} \times 1^{\circ}$ analyzed ozone distributions on the $310 \mathrm{~K}$ isentropic surfaces ( $\sim 2$ to 4

$2 \mathrm{~km}$ asl) at $1200 \mathrm{UT}(0500 \mathrm{PDT})$ on the days before each of the ozone exceedances in

3 Clark County (i.e. May 20, May 24, and June 20). Elevated $\mathrm{O}_{3}$ associated with an upper

4 level low above the Pacific Northwest can be seen above California and Nevada in each

5 instance.

6

$7 \quad$ 4.2 FLEXPART

8 Transport of stratospheric, Asian, and biomass burning tracers to the western U.S.

9 was also followed using the FLEXPART Lagrangian particle dispersion model (version

10 8.1) [Stohl et al., 2005]. FLEXPART does not map the trajectory of an individual parcel

11 as performed by standard trajectory models such as HYSPLIT (Hybrid Single-Particle

12 Lagrangian Integrated Trajectory) [Draxler and Rolph, 2003], but instead calculates the

13 evolving distribution of a multitude of "particles" transported forward in time from a

14 specified source region or backward in time from a specific receptor location. The

15 particles are transported both by the resolved winds and by parameterized subgrid

16 motions including turbulence and convection. For the present study, FLEXPART was

17 driven by the National Centers for Environmental Prediction (NCEP) Global Forecast

18 System (GFS) model (analyses at 0000, 0600, 1200, and 1800 UT; 3-h forecasts at 0300,

190900,1500 , and $2100 \mathrm{UT}$ ) and run at a spatial resolution of $0.5^{\circ} \times 0.5^{\circ}$ with 26 vertical

20 levels. FLEXPART parameterizes turbulence in the boundary layer using the Hanna

21 turbulence scheme [Hanna, 1982] and uses the convection parameterization scheme of

22 Emanuel and Zivkovic-Rothman [1999], which is implemented at each 15-minute model

23 time step, and is intended to describe all types of convection. This scheme includes 
1 entrainment and mixing, cloud microphysical processes, and large-scale control of

2 ensemble convective activity, including the interaction between convective downdrafts

3 and surface fluxes.

4 FLEXPART was run routinely in the source (forward) mode for forecasting during

5 LVOS and the coincident SENEX (Southeast Nexus) field campaigns. The distributions

6 of stratospheric $\mathrm{O}_{3}$, Asian pollution $\mathrm{CO}$, and biomass burning $\mathrm{CO}$ tracers were calculated

7 hourly for an output domain extending from 140 to $90^{\circ} \mathrm{W}$ and from 25 to $70^{\circ} \mathrm{N}$.

8 Horizontal distributions were plotted and archived online for both the boundary layer

9 (below $1.5 \mathrm{~km}$ asl) and for the lower free troposphere (3 to $6 \mathrm{~km}$ asl). The stratospheric

$10 \mathrm{O}_{3}$ tracer was carried by particles released into the stratosphere ( $>2$ potential vorticity

11 units or PVU) and the mixing ratios of $\mathrm{O}_{3}$ calculated using a linear relationship between

$12 \mathrm{O}_{3}$ and potential vorticity ( $\left.60 \mathrm{ppbv} / \mathrm{PVU}\right)$ at the particle origin in the stratosphere. The

$13 \mathrm{O}_{3}$ mixing ratio is conserved and the particle distribution recalculated for up to 20 days

14 with no chemistry. The Asian $\mathrm{CO}$ tracer is based on the amount of $\mathrm{CO}$ released into the

15 boundary layer from anthropogenic sources in East Asia using the EDGAR 3.2 fast track

16 inventory [Olivier et al., 2005], and is followed for 20 days. Biomass burning CO

17 emissions were calculated using the algorithm of Stohl et al. [2007], which incorporates

18 MODIS fire detection data, information on land use, and published emission factors.

19 Both $\mathrm{CO}$ tracers are assumed to be inert. Instead of prescribing a fixed injection height

20 for the fire plume, a probability density function relative to the local PBL height was used

21 [Brioude et al., 2009]. The online tracer distribution plots were updated twice daily as

22 newer GFS input data became available. Figure 12 shows each of the FLEXPART

23 source mode tracer distributions in the boundary layer $(<1.5 \mathrm{~km}$ asl) corresponding to the 
1 higher altitude 310K RAQMS $\mathrm{O}_{3}$ analyses in Figure 11. FLEXPART shows a

2 stratospheric $\mathrm{O}_{3}$ influx of 10-20 ppbv in the vicinity of Clark County that often began

3 during the afternoon or evening before each of the exceedance days, with Asian CO

4 tracer concentrations of $10-15$ ppbv also covering most of Nevada during the first event.

5 The biomass burning contributions are negligible in each case. Note that the $\mathrm{CO}$ color

6 scales differ by about a factor of three for these two tracers to approximately reflect the

7 relative $\mathrm{O}_{3}$ production efficiencies (see below).

8 FLEXPART was also run in the receptor (backward) mode to trace the origins of air

9 transported to Clark County. In this mode, 20,000 particles were launched every hour

10 from a $1^{\circ} \times 1^{\circ}$ domain centered over Angel Peak that includes most of the Las Vegas

11 Valley. The particle distribution was followed backwards in time for up to 10 days and

12 the fraction originating from the boundary layer, free troposphere, and stratosphere

13 calculated, together with the concentrations of $\mathrm{O}_{3}$ originating from the stratosphere and

14 concentrations of $\mathrm{CO}$ transported from Asia or originating from biomass burning. The

15 results from these analyses are plotted as time series (see below).

$17 \quad 4.3$ GFDL AM3

18 The contribution of stratospheric ozone to surface concentrations in the western U.S.

19 during the spring of 2013 was also simulated using the NOAA/GFDL AM3 chemistry-

20 climate model, which includes interactive stratospheric and tropospheric chemistry,

21 nudged to NCEP GFS winds [Lin et al., 2012a; Lin et al., 2012b]. The AM3 simulation

22 of $\mathrm{STT}_{3}$ is entirely driven by winds, with no dependency on the tropopause definition.

23 We implement a stratospheric ozone tracer, defined relative to the dynamically varying 
1 e90 tropopause [Prather et al., 2011], to quantify ozone originating from the stratosphere

2 and account for loss processes in the troposphere. The present study applies a new

3 version of GFDL AM3 at C90 cubed-sphere grid resolution of $\sim 100 \times 100 \mathrm{~km}^{2}$ with daily

4 resolving fire emissions and anthropogenic emissions. Lin et al. [2014, this issue]

5 describe the current version of AM3 in more detail.

6 Figure 13 displays the AM3 median stratospheric contribution to MDA8 surface

7 ozone during May and June of 2013. The spatial distribution appears very similar to the

8 mean 2010 concentrations shown in Figure 1a, but with lower spatial resolution. As in

92010 (cf. Figure 1), the calculated stratospheric contribution to surface ozone is much

10 larger in the Intermountain West than in the Eastern U.S. and along the Gulf Coast, with

11 median concentrations of $20 \mathrm{ppbv}$ or more in many areas. The Asian pollution

12 contribution was not explicitly calculated, but the FLEXPART analyses suggest that it

13 was similar to that shown in Figure 1b.

\section{5. $\mathrm{O}_{3}-\mathrm{CO}-\mathrm{H}_{2} \mathrm{O}$ correlations}

16 Both $\mathrm{CO}$ and $\mathrm{O}_{3}$ have relatively long lifetimes in the free troposphere compared to

17 the timescales of vertical and horizontal transport, and the relationship between the two

18 trace gases has been used to investigate the contribution of photochemistry to

19 tropospheric ozone [Crutzen, 1974; Fishman and Seiler, 1983], mixing between the upper

20 troposphere and lower stratosphere [Herman et al., 1999], long-range transport of ozone

21 [Parrish et al., 1993; Parrish et al., 1998], and to estimate the ozone production

22 efficiency from biomass burning [Jaffe and Wigder, 2012; Wofsy et al., 1992]. Most

23 atmospheric $\mathrm{CO}$ originates from the Earth's surface, either directly from natural and 
1 anthropogenic combustion processes or indirectly through oxidation of $\mathrm{CH}_{4}$ and other

2 volatile organic compounds (VOCs) emitted at the surface [Warneck, 1988].

3 Atmospheric concentrations thus generally decrease with altitude and with distance from

4 the continents. The large contribution of anthropogenic sources to the atmospheric

5 burden means that the atmospheric concentrations have a pronounced latitudinal gradient

6 with a maximum at northern midlatitudes [Seiler and Fishman, 1981]. The

7 concentrations in the lower troposphere above the North Pacific tend to be highest in

8 springtime [Kim et al., 2008]

9 Since $\mathrm{O}_{3}$ is much more abundant in the stratosphere than in the troposphere, the

10 concentrations are usually uncorrelated or negatively correlated with $\mathrm{CO}$ in air

11 originating from the upper troposphere or lower stratosphere. Conversely, $\mathrm{CO}$ and $\mathrm{O}_{3}$

12 tend to be positively correlated in the lower troposphere where much of the $\mathrm{O}_{3}$ is formed

13 through oxidation of $\mathrm{CO}$ and $\mathrm{CH}_{4}$, or through the reactions of $\mathrm{NO}_{\mathrm{x}}$ and $\mathrm{VOCs}$ co-emitted

14 with $\mathrm{CO}$ from combustion sources. Although simple linear relationships are sometimes

15 observed when homogeneous air parcels with different origins mix, the relationship is

16 usually much more complex, particularly in the lower free troposphere and boundary

17 layer. For example, since $\mathrm{O}_{3}$ is a secondary product and not directly emitted from

18 combustion sources like $\mathrm{CO}$, there may be little or no correlation in urban or polluted

19 areas where there are distributed combustion sources, and negative correlations can arise

20 when $\mathrm{O}_{3}$ is destroyed through titration by $\mathrm{NO}$ in fresh combustion plumes or by surface

21 deposition, as is often the case in the nocturnal boundary layer.

22 The utility of the $\mathrm{O}_{3}-\mathrm{CO}$ correlation plots for investigating air parcel origins can be

23 improved by including simultaneous $\mathrm{H}_{2} \mathrm{O}$ measurements. Water vapor is not a conserved 
1 quantity in the troposphere on timescales longer than a few days, but the concentrations

2 are usually much lower in the free troposphere than in the boundary layer and lower still

3 in the lowermost stratosphere. Thus, stratospheric intrusions are usually drier than long-

4 range transport layers, which are in turn drier than polluted boundary layer air or biomass

5 burning plumes that usually contain large amounts of water vapor.

$6 \quad$ Figure 14a displays a scatter plot of all the 1-min in situ $\mathrm{O}_{3}$ and $\mathrm{CO}$ data acquired

7 during LVOS at Angel Peak between May 19 and June 29. The points are color-coded

8 by specific humidity with the highest $\mathrm{O}_{3}$ generally associated with drier air. The highest

9 CO concentrations were associated with the plume from the Powerhouse Fire (see below)

10 that engulfed Angel Peak on June 2. Although the measurements show an overall

11 positive correlation, the data represent many different air parcels and are highly scattered.

12 However, Figure 14b shows that simple relationships consistent with the mixing of two

13 homogeneous air parcels can be identified, in some cases, when the measurements from

14 much shorter intervals are isolated. This plot isolates several examples of mixing lines

15 observed over $3 \mathrm{~h}$ intervals that are believed to be indicative of the mixing between free

16 tropospheric background air and air parcels influenced by the stratosphere (ST: high $\mathrm{O}_{3}$,

17 very low $\mathrm{H}_{2} \mathrm{O}$, negative $\mathrm{O}_{3}-\mathrm{CO}$ correlation), transport from Asia (AS: high $\mathrm{O}_{3}$, low $\mathrm{H}_{2} \mathrm{O}$,

18 positive $\mathrm{O}_{3}$-CO correlation), wildfire/urban plume (LA/BB: high $\mathrm{CO}$, moderate $\mathrm{H}_{2} \mathrm{O}$,

19 positive $\mathrm{O}_{3}-\mathrm{CO}$ correlation), the subtropical marine boundary layer air (MB: low $\mathrm{O}_{3}$ and

$20 \mathrm{CO}$, relatively high $\mathrm{H}_{2} \mathrm{O}$, positive $\mathrm{O}_{3}-\mathrm{CO}$ correlation) and finally, regional photochemical

21 production and transport from the valley mixed with the subtropical air (MB/LV:

22 moderate $\mathrm{O}_{3}, \mathrm{CO}$, high $\mathrm{H}_{2} \mathrm{O}$, positive $\mathrm{O}_{3}-\mathrm{CO}$ correlation). A wide range of slopes can

23 result when air parcels of different origin are combined, but the mingling of air from the 
1 UT/LS with air from the free troposphere or boundary layer will create mixing lines with

2 negative or zero slopes and an gradient in $\mathrm{H}_{2} \mathrm{O}$ (Figure 14c) [Brioude et al., 2007].

3 The simple analysis applied to the examples in Figure 14b was extended to the

4 entire time series with the linear regression calculated at 15 minutes intervals for

5 overlapping $3 \mathrm{~h}$ periods. Figure 15a plots the Angel Peak in situ $\mathrm{O}_{3}$ mixing ratios color-

6 coded by the resulting slopes with negative values in red. Only data acquired between

$7 \quad 1300$ and 2200 PDT are included in the analysis to reduce the influence of surface

8 deposition, and symbols are plotted only when the coefficient of determination (i.e. $\mathrm{R}^{2}$ ) is

9 greater than 0.5 . Figures $15 \mathrm{~b}$ and $15 \mathrm{c}$ are similar, but show the $\mathrm{O}_{3}$ concentrations color-

10 coded by the $\mathrm{H}_{2} \mathrm{O}$ and $\mathrm{CO}$ concentrations. This analysis shows that there were

11 statistically significant negative correlations before each of the exceedance days, as well

12 as on May 28 when TOPAZ detected a high $\mathrm{O}_{3}$ layer aloft (Figure 6), but the

13 concentrations remained relatively low in the valley (MDA8 $\leq 64 \mathrm{ppbv}$ ). All three

14 exceedance days were associated with dry air and relatively low CO concentrations

15 consistent with descending air of UT/LS origin.

\section{6. Stratospheric contribution to surface ozone during LVOS}

18 The FLEXPART back trajectories and AM3 analyses can be used together with the

19 observations to estimate the contributions of stratospheric intrusions, transport from Asia,

20 and wild fires to the surface ozone measured at Angel Peak and surrounding areas.

21 Figure 16 plots the surface $\mathrm{O}_{3}$ concentrations from Angel Peak color-coded by the

22 contributions from the FLEXPART (a) stratospheric $\mathrm{O}_{3}$, (b) Asian $\mathrm{CO}$, and (c) biomass

23 burning CO tracers at $1000 \mathrm{~m}$ asl or just above the elevation of the Las Vegas Valley. 
1 The vertical yellow bars mark the three Clark County exceedance days as before. The

2 back trajectories show stratospheric contributions of 15 to $30 \mathrm{ppbv}$ to the $\mathrm{O}_{3}$ at $1000 \mathrm{~m}$

3 asl for extended periods in late May and immediately before or on each of the three

4 exceedance days. The FLEXPART Asian CO tracer is generally much smaller, and

5 exceeded 10 ppbv only on June 17-18 when it was 12 ppbv (cf. Figure 14b). The

6 corresponding $\mathrm{O}_{3}$ influx is likely smaller, but the 75 ppbv ozone NAAQS was exceeded

7 at Angel Peak on both days and nearly equaled at Joe Neal (74 ppbv) on June 17. The

82008 NAAQS was also approached (73 ppbv) at Great Basin National Park on June 17

9 and exceeded (76 ppbv) on June 18. The Asian tracer also had significant concentrations

10 ( $\sim 8 \mathrm{ppbv}$ of CO) on May 21, the first exceedance day, and during the last week of May,

11 but always remained much smaller than the corresponding stratospheric contribution.

12 The contributions from the FLEXPART biomass-burning tracer to surface $\mathrm{CO}$ in

13 Clark County exceeded 8 ppbv only on June 2, when the plume from the Powerhouse

14 Fire passed through. The CO tracer concentrations reached $\sim 25$ ppbv or about $25 \%$ of

15 the measured enhancement of $100 \mathrm{ppbv}$ (cf. Figure $7 \mathrm{~b}$ ). The maximum $\mathrm{CO}$ and $\mathrm{O}_{3}$

16 concentrations measured in this plume were $210 \mathrm{ppb} \mathrm{CO}$ and $85 \mathrm{ppb} \mathrm{O}_{3}$. Assuming the

17 baseline values are $100 \mathrm{ppbv}$ of $\mathrm{CO}$ and $50 \mathrm{ppbv}$ of $\mathrm{O}_{3}$, the plume enhancements are 35

$18 \mathrm{ppbv}_{3}$ and $110 \mathrm{ppbv} \mathrm{CO}$, with a ratio of 0.32 . This implies that the Powerhouse fire

19 plume contributed less than 3 ppbv of $\mathrm{O}_{3}$ to the surface concentrations on June 2, and

20 suggests that the impact of biomass burning on surface ozone during the three

21 exceedance days during LVOS negligible. However, FLEXPART analyses from before

22 and after the LVOS campaign (not shown) suggest that the emission plumes from the

23 24,251 acre Springs Fire in Ventura County, CA, and the 27,881 acre Carpenter 1 Fire in 
1 Clark County and 5,400 acre Dean Peak Fire in NW Arizona were most likely

2 responsible for the ozone exceedances that occurred in Clark County on May 4, July 3

3 and July 20, 2013. The latter fire, which started the day after the record high temperature

$4\left(47^{\circ} \mathrm{C}\right.$ or $\left.117^{\circ} \mathrm{F}\right)$ in Las Vegas was tied, forced evacuation of the area surrounding Angel

5 Peak and burned a chaparral and juniper mix similar to that consumed in the Powerhouse

6 Fire. Interestingly, both the Springs and Powerhouse Fires started soon after the passage

7 of upper level troughs, supporting the suggestion (Paul Schultz, NOAA ESRL, personal

8 communication) that high winds and descending dry air associated with stratospheric

9 intrusions may exacerbate wildfires in the western U.S. during the late spring and early

10 summer.

11 The stratospheric contribution to surface ozone at Angel Peak and surrounding areas

12 was calculated using the AM3 model [Lin et al. this issue]. Figure 17 displays time

13 series comparing the calculated May to July $\mathrm{MDA} 8 \mathrm{O}_{3}$ concentrations for Death Valley

14 NP, Angel Peak (LVOS only), Jean, and Joe Neal to the observations. Here, the black

15 lines represent the measured MDA8 concentrations and the red traces the modeled

16 concentrations; the blue traces isolate the stratospheric contribution to the model total

17 concentrations. The modeled ozone includes contributions from North American

18 pollution and wildfires in addition to the stratosphere and long-range transport from Asia.

19 As before, the horizontal dashed line represents the 2008 NAAQS of 75 ppbv. The AM3

20 modeled concentrations are generally in excellent agreement with the observations,

21 capturing most of the day-to-day variability and ozone peaks as well as the unusually low

22 ozone concentrations associated with the large-scale incursion of subtropical air in late

23 June. The model does particularly well at Jean, where linear regression between the 
1 calculated and observed MDA8 ozone during LVOS gives AM3 =

$2(0.86 \pm 0.08) * \mathrm{OBS}+11 \pm 5 \mathrm{ppbv}$ with $\mathrm{R}^{2}=0.77$. The mean ratio is $1.03 \pm 0.01$. The worst

3 agreement $\left(\mathrm{AM} 3=(0.73 \pm 0.13) * \mathrm{OBS}+16 \pm 8 \mathrm{ppbv} \mathrm{R}^{2}=0.46\right.$ and a mean ratio of

$4 \quad 0.98 \pm 0.02)$ is found for Joe Neal, which is the site most impacted by local urban sources.

5 Indeed, the greatest divergence between the model results and the Joe Neal observations

6 was immediately after the subtropical incursion when locally formed ozone was a large

7 fraction of the total (cf. Figures 6 and 9); the coefficient of determination increases from

$8 \mathrm{R}^{2}=0.46$ to $\mathrm{R}^{2}=0.57$ if the measurements from June 28 are omitted.

9 The mean MDA8 surface ozone calculated for Angel Peak by AM3 averaged

$1064 \pm 10 \mathrm{ppbv}$ over the course of LVOS, nearly identical to the measured value of $65 \pm 10$

11 ppbv. The stratospheric component averaged $18 \pm 10 \mathrm{ppbv}$ over this period. The

12 corresponding values for the period from May 19 to May 31 when TOPAZ detected

13 frequent ozone layers aloft were $69 \pm 9 \mathrm{ppbv}(\mathrm{AM} 3)$ and $71 \pm 7 \mathrm{ppbv}$ (observed), with an

14 AM3 stratospheric component of $27 \pm 9$ ppbv. The largest single day AM3 STT

15 contribution was 45 ppbv on May 23 (and 33 ppbv on May 24), one day before the

16 highest observed values and two days before the second Clark County exceedance event

17 on May 25. The AM3 calculated stratospheric contribution was at least 25 ppbv on each

18 of the three LVOS exceedance days, with contributions in excess of 30 ppbv occurring on

19 May 1, 19, and 30, and on June 13 and 20.

20 Comparisons between surface concentrations and those calculated using a previous

21 version of AM3 found that the AM3 stratospheric contribution was sometimes biased too

22 high [Lin et al., 2012a]. However, the excellent agreement between AM3 and the

23 observations seen in Figure 17 suggests that this is not the case for the present results, 
1 which are derived from a significantly improved model [Lin et al., this issue]. Figure

2 18a compares the AM3 results for surface ozone at Angel Peak during LVOS with the

3 concentrations derived from the FLEXPART back trajectories. The correlation between

4 the two time series is excellent $\left(\mathrm{R}^{2}=0.64\right)$, but the stratospheric contributions calculated

5 by FLEXPART are about a factor of two smaller than those derived using AM3. Figure

$618 \mathrm{~b}$ shows that the agreement between the AM3 results and the measured concentrations

7 is severely degraded if the AM3 stratospheric contribution is increased by $50 \%$, or

8 decreased by $50 \%$ to agree with the FLEXPART results. This implies that the AM3

9 concentrations are the more accurate. One possible explanation for the systematic

10 differences is that the spatial and temporal boundaries assumed for the FLEXPART

11 source domain excludes a significant contribution from aged stratospheric air. Another

12 possibility is that the assumed $2 \mathrm{PVU}$ definition of the tropopause may have been too

13 restrictive. Note that neither of these possibilities will change the biomass burning and

14 Asian tracer results. In any event, the excellent correlation shows that both models

15 capture the important transport processes.

\section{7. Summary and Conclusions}

18 The LVOS measurement and model results provide compelling evidence that STT,

19 and to a lesser extent, transported Asian pollution significantly increased surface $\mathrm{O}_{3}$

20 concentrations in Clark County, NV during the late spring and early summer of 2013.

21 Both measurements and model analyses suggest that these transport processes directly

22 contributed to the exceedances of the 2008 ozone NAAQS reported at one or more of the

23 Clark County monitors on May 21, May 25, and June 21. The AM3 model results 
1 suggest that the stratospheric contribution to the surface MDA8 $\mathrm{O}_{3}$ was at least $30 \mathrm{ppbv}$

2 during each of these events, which were characterized by the entrainment of ozone-rich

3 air that had descended from the UT/LS to the lower free troposphere over a large area

4 during the preceding 1-2 days. There were more exceedance days at Angel Peak than in

5 the Las Vegas Valley, consistent with the downward transport of $\mathrm{O}_{3}$ into Clark County

6 from aloft. These findings are consistent with earlier work, including the $50 \mathrm{~km} \mathrm{AM3}$

7 model results, which showed Clark County to be a major receptor of transported ozone

8 from STT and Asian pollution sources in the spring of 2010.

9 The Angel Peak measurements and FLEXPART tracer distributions also show that

10 emissions from the Powerhouse Fire in southern California contributed to elevated

$11 \mathrm{MDA}_{8} \mathrm{O}_{3}(73 \mathrm{ppbv})$ in Clark County on June 2. The FLEXPART tracer distributions

12 also suggest that regional wildfires contributed to exceedances of the NAAQS before or

13 after the LVOS campaign on May 4, July 3, and July 20, 2013, and that STT also

14 contributed to the May 4 event. These findings imply that all 6 of the $\mathrm{O}_{3}$ exceedance

15 days in Clark County during 2013 were largely due to outside influences.

16 The mean surface MDA8 ozone at Jean, NV in rural Clark County was $67 \mathrm{ppbv}$

17 during May and June of 2013, which is only 8 ppbv less than the current 2008 NAAQS

18 and greater than some values that are currently being considered

19 (www.epa.gov/oaqps001/greenbk/hindex.html). The number of exceedance days in

20 Clark County during the 43-day LVOS field campaign would have increased from 3 to 14

21 if the NAAQS had been 70 ppbv instead of 75 ppbv, and from 3 to 25 if the NAAQS had

22 been 65 ppbv. In other words, exceedances of the NAAQS generated by natural sources 
1 (i.e. stratospheric intrusions) would have occurred on $60 \%$ of the days during LVOS,

2 making these events the rule rather than the exception.

4 Acknowledgements

5 This work was funded primarily by the Clark County Department of Air Quality

6 under contract no. CBE 602948-13. We would also like to acknowledge support from the

7 NOAA Health of the Atmosphere and Climate Programs and the NASA Tropospheric

8 Ozone Lidar Network (TOLNet, http://www-air.larc.nasa.gov/missions/TOLNet/). The

9 authors would like to thank Zheng Li, Mickey Turner, Dennis Randel, and the other staff

10 of the Clark County Department of Air Quality for their assistance and hospitality during

11 LVOS. We are also grateful to John Vimont of the U.S. National Park Service and

12 Jessica Ward of Air Resource Specialists, Inc. for providing the 1-minute NPS ozone data.

13 The views, opinions, and findings contained in this report are those of the author(s) and

14 should not be construed as an official National Oceanic and Atmospheric Administration

15 or U.S. Government position, policy, or decision.

16

17 References

18

19

20

Alvarez II, R. J., et al. (2011), Development and Application of a Compact, Tunable, Solid-State Airborne Ozone Lidar System for Boundary Layer Profiling, Journal of Atmospheric and Oceanic Technology, 28(10), 1258-1272, doi:Doi 10.1175/Jtech-D-10-05044.1. 
Ambrose, J. L., D. R. Reidmiller, and D. A. Jaffe (2011), Causes of high $\mathrm{O}_{3}$ in the lower free troposphere over the Pacific Northwest as observed at the Mt. Bachelor Observatory., Atmos. Envir., 45, 5302-5315, doi:10.1016/j.atmosenv.2011.06.056.

Brioude, J., et al. (2009), Effect of biomass burning on marine stratocumulus clouds off the California coast, Atmos. Chem. Phys., 9(22), 8841-8856.

Brioude, J., et al. (2007), Mixing between a stratospheric intrusion and a biomass burning plume, Atmospheric Chemistry and Physics, 7(16), 4229-4235.

Brown-Steiner, B., and P. Hess (2011), Asian influence on surface ozone in the United States: A comparison of chemistry, seasonality, and transport mechanisms, $J$. Geophys. Res.-Atmos., 116, doi:Artn D17309, Doi 10.1029/2011jd015846.

Butler, T. J., F. M. Vermeylen, M. Rury, G. E. Likens, B. Lee, G. E. Bowker, and L. McCluney (2011), Response of ozone and nitrate to stationary source NOx emission reductions in the eastern USA, Atmospheric Environment, 45(5), 10841094, doi:Doi 10.1016/J.Atmosenv.2010.11.040.

Cooper, O. R., et al. (2004a), On the life cycle of a stratospheric intrusion and its dispersion into polluted warm conveyor belts, J. Geophys. Res., 109(D23). Cooper, O. R., et al. (2004b), A case study of trans-Pacific warm conveyor belt transport: The influence of merging airstreams on trace gas import to North America, J. Geophys. Res., 108(D23S08), doi:10.1029/2003JD003624.

Cooper, O. R., R.-S. Gao, D. Tarasick, T. Leblanc, and C. Sweeney (2012), Long-term ozone trends at rural ozone monitoring sites across the United States, 1990-2010, J. Geophys. Res, 117, doi:10.1029/2012JD018261. 
Crutzen, P. J. (1974), Photochemical reactions initiated by and influencing ozone in unpolluted tropospheric air, Tellus, 26, 47-57.

Draxler, R. R., and G. D. Rolph (2003), HYSPLIT (HYbrid Single-Particle Lagrangian Integrated Trajectory) Model access via NOAA ARL READY Website (http://www.arl.noaa.gov/HYSPLIT.php), edited, NOAA Air Resources Laboratory, Silver Spring, MD.

Emanuel, K. A., and M. Zivkovic-Rothman (1999), Development and evaluation of a convective scheme for use in climate models, J. Atmos. Sci., 56, 1766-1782.

EPA (2012), Our Nation's Air: Status and trends through 2010Rep., U.S. Environmental Protection Agency Research Triangle Park, North Carolina.

Fishman, J., and W. Seiler (1983), Correlative nature of ozone and carbon monoxide in the troposphere: Implications for the tropospheric ozone budget, J. Geophys. Res., 88, 3662-3670.

Hanna, S. R. (1982), Applications in air pollution modeling, in Atmospheric Turbulence and Air Pollution Modelling, edited by F. T. M. Nieuwstadt and H. van Dop, pp. 275-310,, D. Reidel Publishing Company, Dordrecht, Holland. He, H., et al. (2013), Trends in emissions and concentrations of air pollutants in the lower troposphere in the Baltimore/Washington airshed from 1997 to 2011, Atmos. Chem. Phys., 13(15), 7859-7874, doi:10.5194/acp-13-7859-2013.

Herman, R. L., et al. (1999), Measurements of CO in the upper troposphere and lower stratosphere, Chemosphere: Global Change Science, 1, 173-183.

Holloway, J. S., R. O. Jakoubek, D. D. Parrish, C. Gerbig, A. Volz-Thomas, S. Schmitgen, A. Fried, B. Wert, B. Henry, and J. R. Drummond (2000), Airborne 
1 intercomparison of vacuum ultraviolet fluorescence and tunable diode laser

2 absorption measurements of tropospheric carbon monoxide, J. Geophys. Res.-

3 Atmos., 105(D19), 24251-24261, doi:Doi 10.1029/2000jd900237.

$4 \quad$ Holzer, M., and T. M. Hall (2007), Low-level transpacific transport, Journal of

$5 \quad$ Geophysical Research, 112, D09103.

6 Jacob, D. J., J. A. Logan, and P. P. Murti (1999), Effect of rising Asian emissions on

7 surface ozone in the United States, Geophysical Research Letters, 26(14), 2175-

$8 \quad$ 2178, doi:Doi 10.1029/1999g1900450.

9 Jaffe, D. A., and N. L. Wigder (2012), Ozone production from wildfires: A critical

10 review, Atmospheric Environment, 51, 1-10, doi:Doi

$11 \quad$ 10.1016/J.Atmosenv.2011.11.063.

12 James, P., A. Stohl, C. Forster, S. Eckhardt, P. Seibert, and A. Frank (2003), A 15-

13 year climatology of stratosphere-troposphere exchange with a Lagrangian particle

14 dispersion model 2. Mean climate and seasonal variability J. Geophys. Res., 108,

$15 \quad$ doi:10.1029/2002JD002639.

16 Johnson, W. B., and W. Viezee (1981), Stratospheric ozone in the lower troposphere-I.

17 presentation and interpretation of aircraft measurements, Atmos. Environ., 15,

$18 \quad 1309-1323$.

19 Kim, H. S., P. P. Tans, and P. C. Novelli (2008), On the regional background levels of 20 carbon monoxide observed in East Asia during 1991 similar to 2004, Air Qual

21 Atmos Hlth, 1(1), 37-44, doi:Doi 10.1007/S11869-008-0001-3. 
1 Langford, A. O., K. C. Aikin, C. S. Eubank, and E. J. Williams (2009), Stratospheric

2 contribution to high surface ozone in Colorado during springtime, Geophys. Res.

$3 \quad$ Lett., doi:10.1029/2009GL038367.

4 Langford, A. O., J. Brioude, O. R. Cooper, C. J. Senff, R. J. Alvarez, R. M. Hardesty, 5 B. J. Johnson, and S. J. Oltmans (2012), Stratospheric influence on surface ozone 6 in the Los Angeles area during late spring and early summer of 2010, J. Geophys. $7 \quad$ Res.-Atmos., 117, doi:Artn D00v06

$8 \quad$ Doi $10.1029 / 2011 \mathrm{jd} 016766$.

9 Langford, A. O., C. J. Senff, R. J. Alvarez, R. M. Banta, and R. M. Hardesty (2010),

10 Long-range transport of ozone from the Los Angeles Basin: A case study, $11 \quad$ Geophysical Research Letters, 37, doi:Artn L06807

12 Doi $10.1029 / 2010 \mathrm{~g} 1042507$.

13 Lefohn, A. S., D. Shadwick, and S. J. Oltmans (2010), Characterizing changes in 14 surface ozone levels in metropolitan and rural areas in the United States for 1980152008 and 1994-2008, Atmospheric Environment, 44(39), 5199-5210, doi:Doi $16 \quad$ 10.1016/J.Atmosenv.2010.08.049.

17 Lefohn, A. S., H. Wernli, D. Shadwick, S. Limbach, S. J. Oltmans, and M. Shapiro

18 (2011), The importance of stratospheric-tropospheric transport in affecting 19 surface ozone concentrations in the western and northern tier of the United States, 20 Atmospheric Environment, 45(28), 4845-4857, doi:Doi

$21 \quad$ 10.1016/J.Atmosenv.2011.06.014.

22 Liang, Q., L. Jaeglé, D. Jaffe, P. Weiss-Penzias, A. Heckman, and J. A. Snow (2004), 23 Long-range transport of Asian pollution to the northeast Pacific: Seasonal 
variations and transport pathways of carbon monoxide, Journal of Geophysical Research, 109, doi:10.1029/2003JD004402.

Liang, Q., L. Jaegle, and J. M. Wallace (2005), Meteorological indices for Asian outflow and transpacific transport on daily to interannual timescales, Journal of Geophysical Research, 110(D18), D18308.

Lin, M. Y., A. M. Fiore, O. R. Cooper, L. W. Horowitz, A. O. Langford, H. Levy, B. J. Johnson, V. Naik, S. J. Oltmans, and C. J. Senff (2012a), Springtime high surface ozone events over the western United States: Quantifying the role of stratospheric intrusions, J. Geophys. Res.-Atmos., 117, doi:Artn D00v22

Doi 10.1029/2012jd018151.

Lin, M. Y., et al. (2012b), Transport of Asian ozone pollution into surface air over the western United States in spring, J. Geophys. Res.-Atmos., 117, doi:Artn D00v07 Doi 10.1029/2011jd016961.

Neuman, J. A., et al. (2011), Ozone transport from the free troposphere to the Los Angeles basin, J. Geophys. Res., doi:10.1029/2011JD016919.

Olivier, J. G. J., J. A. Van Aardenne, F. Dentener, L. Ganzeveld, and J. A. H. W. Peters (2005), Recent trends in global greenhouse gas emissions: regional trends and spatial distribution of key sources, in Non-CO2 Greenhouse Gases (NCGG-4) edited by A. v. Amstel, pp. 325-330, Millpress, Rotterdam.

Parrish, D. D., J. S. Holloway, M. Trainer, P. C. Murphy, G. L. Forbes, and F. C. Fehsenfeld (1993), Export of North American ozone pollution to the North Atlantic Ocean, Science, 259, 1436-1439. 
1 Parrish, D. D., M. Trainer, J. S. Holloway, J. E. Yee, M. S. Warshawsky, F. C.

2 Fehsenfeld, G. L. Forbes, and J. L. Moody (1998), Relationships between ozone

3 and carbon monoxide at surface sites in the North Atlantic region, J. Geophys.

4 Res.-Atmos., 103(D11), 13357-13376, doi:Doi 10.1029/98jd00376.

$5 \quad$ Pierce, R. B., et al. (2003), Regional Air Quality Modeling System (RAQMS)

6 predictions of the tropospheric ozone budget over east Asia, J. Geophys. Res.-

$7 \quad$ Atmos., 108(D21), doi:Artn 8825

$8 \quad$ Doi $10.1029 / 2002 j \mathrm{~d} 003176$.

9 Pierce, R. B., et al. (2007), Chemical data assimilation estimates of continental US

10 ozone and nitrogen budgets during the Intercontinental Chemical Transport

11 Experiment-North America, J. Geophys. Res.-Atmos., 112(D12), doi:Artn D12s21

12 Doi 10.1029/2006jd007722.

13 Prather, M. J., X. Zhu, Q. Tang, J. N. Hsu, and J. L. Neu (2011), An atmospheric

14 chemist in search of the tropopause, J. Geophys. Res.-Atmos., 116, doi:Artn

$15 \quad$ D04306

16 Doi $10.1029 / 2010 j \mathrm{j} 014939$.

17 Seiler, W., and J. Fishman (1981), The Distribution of Carbon-Monoxide and Ozone

18 in the Free Troposphere, Journal of Geophysical Research-Oceans and

19 Atmospheres, 86(Nc8), 7255-7265, doi:Doi 10.1029/Jc086ic08p07255.

20 Sprenger, M., and H. Wernli (2003), A northern hemisphere climatology of cross-

21 tropopause exchange for the ERA15 time period (1979-1993), J. Geophys. Res.,

$22 \quad$ 108, doi:10.1029/2002JD002636. 
Stohl, A. (2001), A 1-year Lagrangian "climatology" of airstreams in the Northern Hemisphere troposphere and lowermost stratosphere, J. Geophys. Res., 106, 7263-7279.

Stohl, A., et al. (2007), Arctic smoke - record high air pollution levels in the European Arctic due to agricultural fires in Eastern Europe in spring 2006, Atmos. Chem. Phys., 7, 511-534.

Stohl, A., C. Forster, A. Frank, P. Seibert, and G. Wotawa (2005), Technical note: The Lagrangian particle dispersion model FLEXPART version 6.2, Atmos. Chem. Phys., 5, 2461-2474.

Stohl, A., and T. Trickl (1999), A textbook example of long-range transport: Simultaneous observation of ozone maxima of stratospheric and North American origin in the free troposphere over Europe, J. Geophys. Res., 104, 30445-30462. Warneck, P. (1988), Chemistry of the Natural Atmosphere, 753 pp., Academic Press, San Diego.

Wernli, H., and M. Bourqui (2002), A Lagrangian "1-year climatology" of (deep) cross-tropopause exchange in the extratropical Northern Hemisphere, J. Geophys. Res., 107(D1-D2), doi:10.1029/2001JD000812.

White, A. B., C. J. Senff, and R. M. Banta (1999), A comparison of mixing depths observed by ground-based wind profilers and an airborne lidar, J. Atmos. Oceanic Technol., 16, 584-590.

Williams, E. J., F. C. Fehsenfeld, B. T. Jobson, W. C. Kuster, P. D. Goldan, J. Stutz, and W. A. McClenny (2006), Comparison of ultraviolet absorbance, 
chemiluminescence, and DOAS instruments for ambient ozone monitoring, Environmental Science and Technology, 40(18), doi:10.1021/es0523542.

3 Wofsy, S. C., et al. (1992), Atmospheric Chemistry in the Arctic and Sub-Arctic -

4 Influence of Natural Fires, Industrial Emissions, and Stratospheric Inputs, $J$.

5 Geophys. Res.-Atmos., 97(D15), 16731-16746.

6 Zhang, L., D. J. Jacob, N. V. Downey, D. A. Wood, D. Blewitt, C. C. Carouge, A. van

7 Donkelaar, D. B. A. Jones, L. T. Murray, and Y. X. Wang (2011), Improved

8 estimate of the policy-relevant background ozone in the United States using the

9 GEOS-Chem global model with 1/2 degrees x 2/3 degrees horizontal resolution

10 over North America, Atmospheric Environment, 45(37), 6769-6776, doi:Doi

$11 \quad$ 10.1016/J.Atmosenv.2011.07.054.

12

13

14 


\section{Figures}

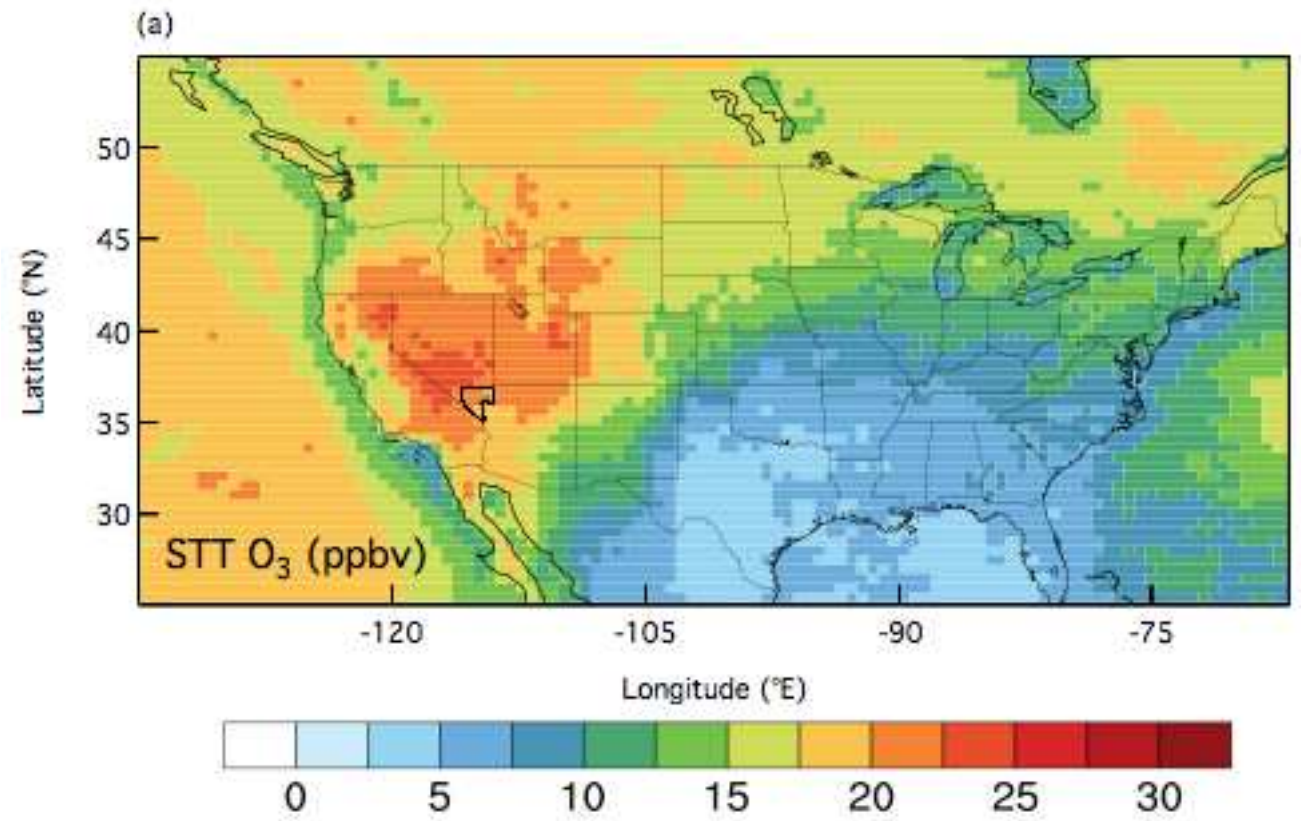

(b)

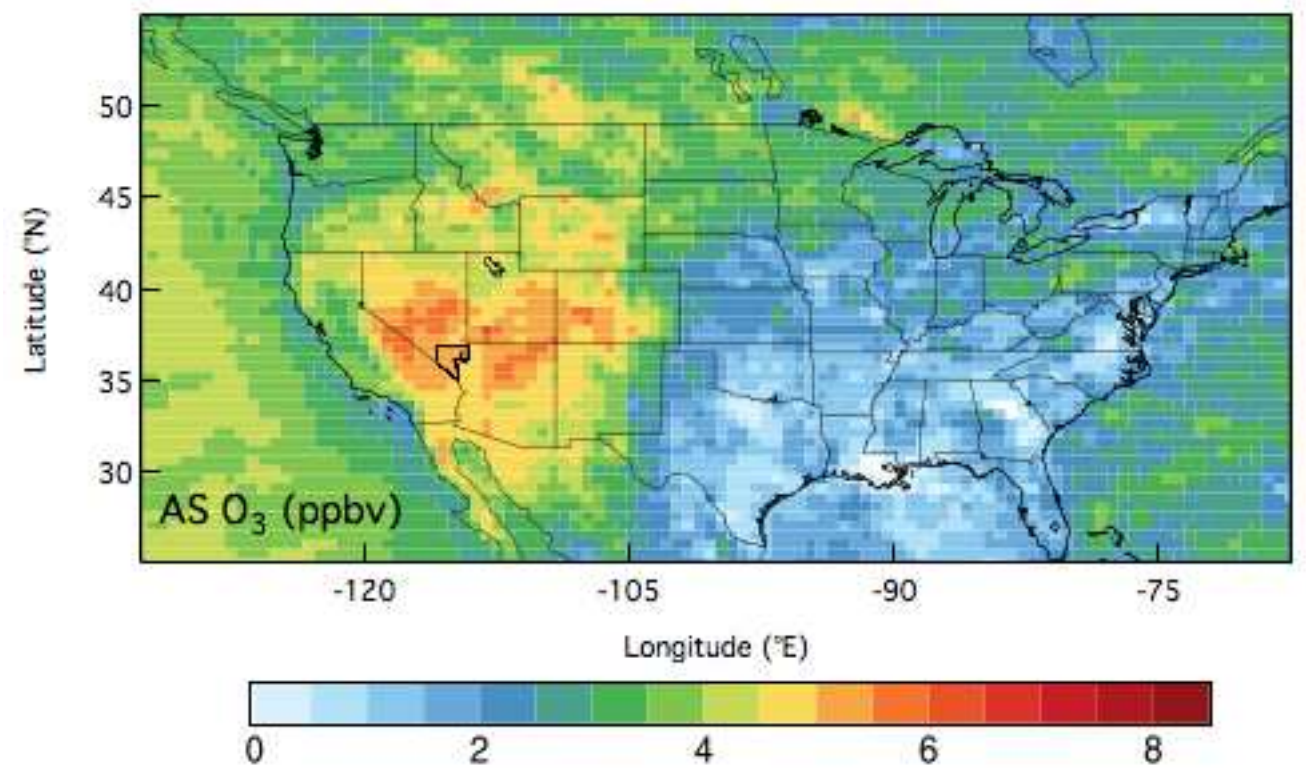

6 Figure 1. NOAA GFDL AM3 model mean contributions of (a) STT, and (b) Asian 7 pollution, to MDA8 surface $\mathrm{O}_{3}$ during May and June of 2010. The resolution is $50 \mathrm{~km} \mathrm{x}$ $850 \mathrm{~km}$. Note the different color scales. Clark County, NV is outlined in black. Adapted 9 from Lin et al. [2012a, 2012b]. 


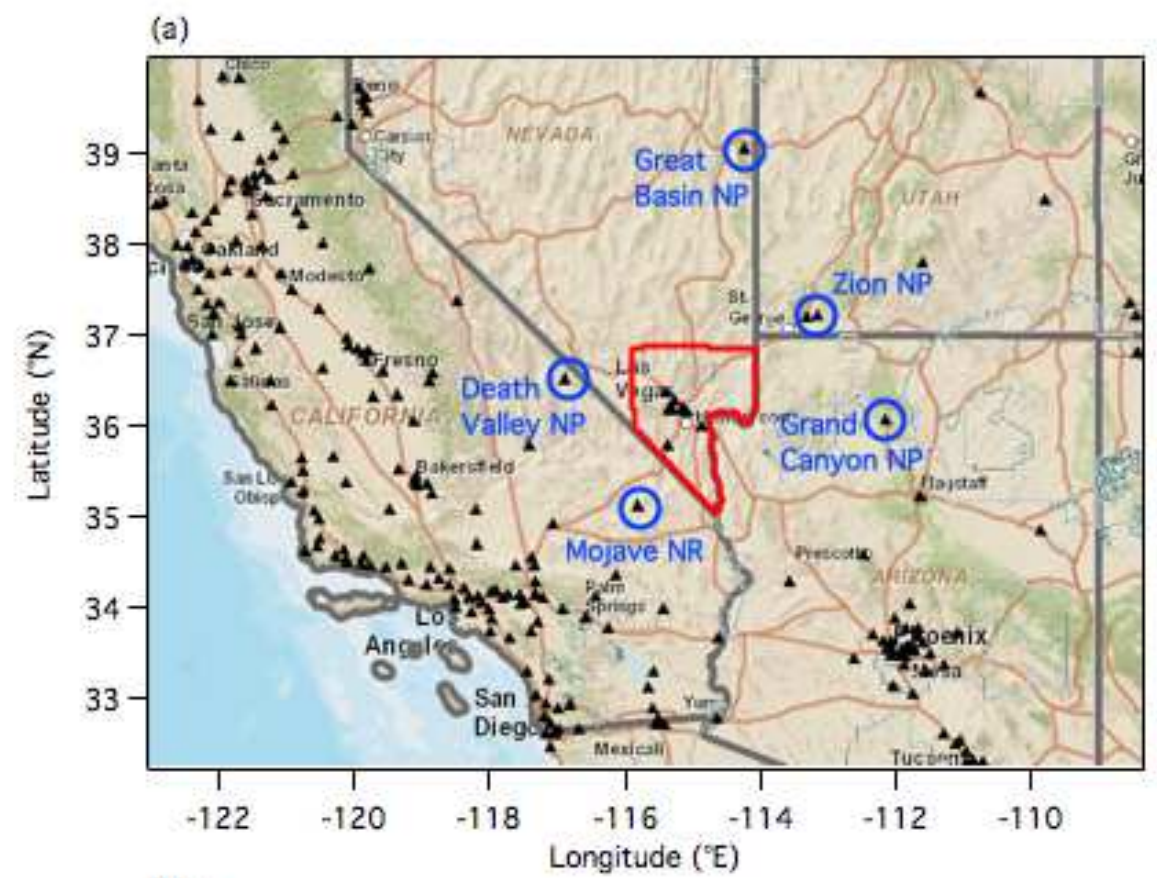

(b)

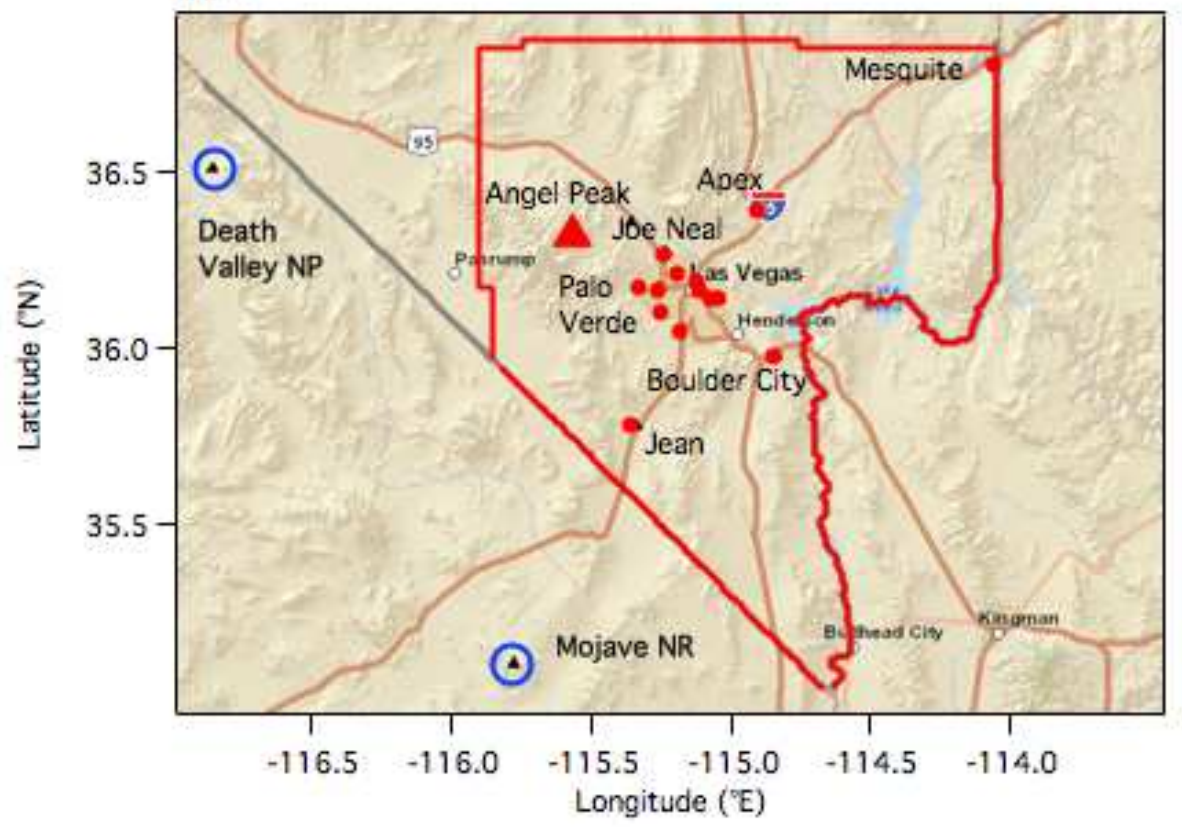

Figure 2. (a) Map of the southwestern United States showing the regulatory ozone monitors reporting to the U.S. EPA AirNow network (filled triangles). Clark County, $\mathrm{NV}$ is outlined in red. The monitors within the blue open circles are maintained by the U.S. National Park Service. (b) Expanded view of Clark County with the monitors maintained by the Clark County Department of Air Quality shown as filled red circles. 


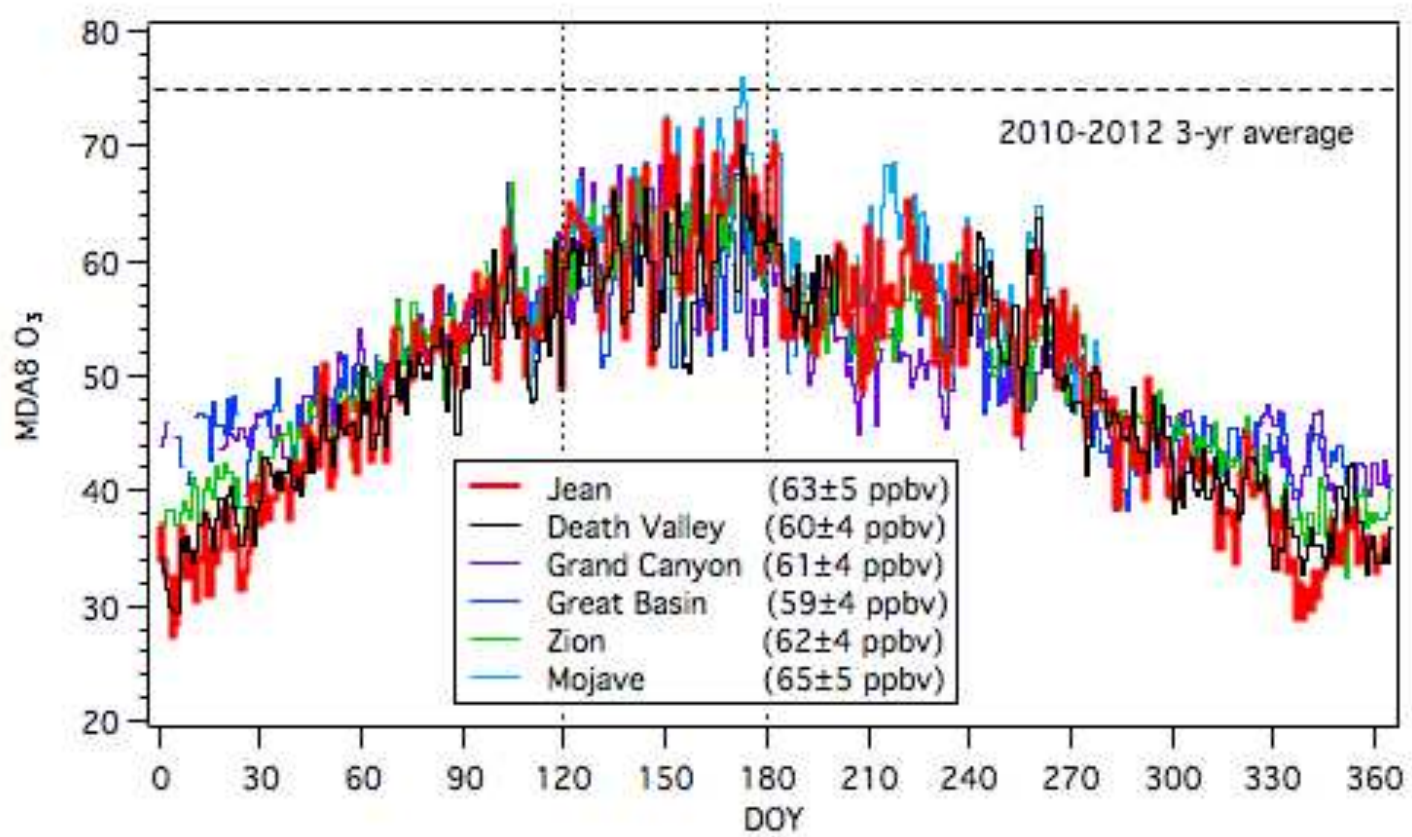

3

4

5

6

Figure 3. Mean MDA8 ozone measured by the CC/DAQ monitor at Jean, NV, Death Valley National Park, Great Basin National Park, Zion National Park, Grand Canyon National Park, and the Mojave National Reserve (seasonal) from 2010 to 2012. The mean values from each site during May and June (vertical dotted lines) are shown in the box. The horizontal dashed line indicates the 2008 8-h NAAQS of 75 ppbv. 
(a)

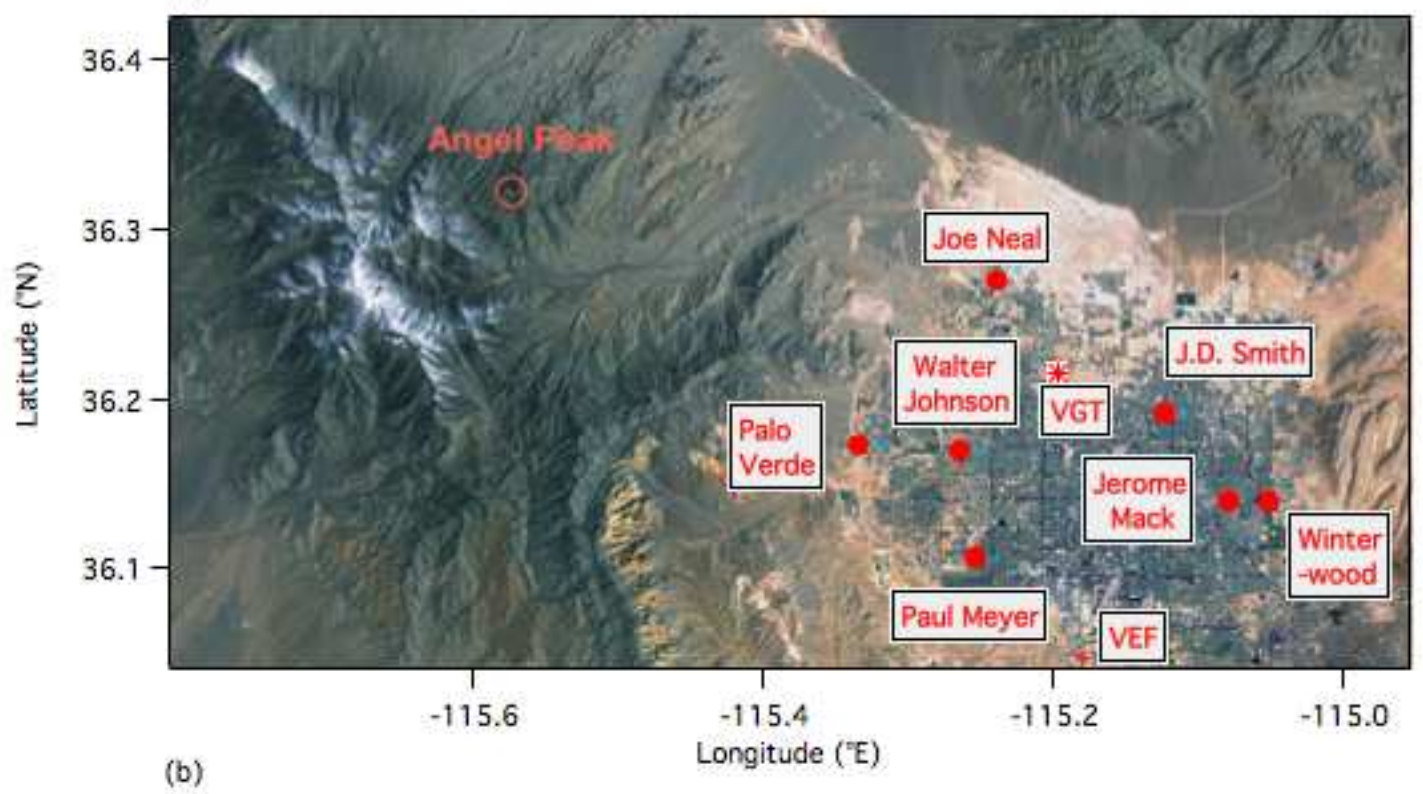

(b)

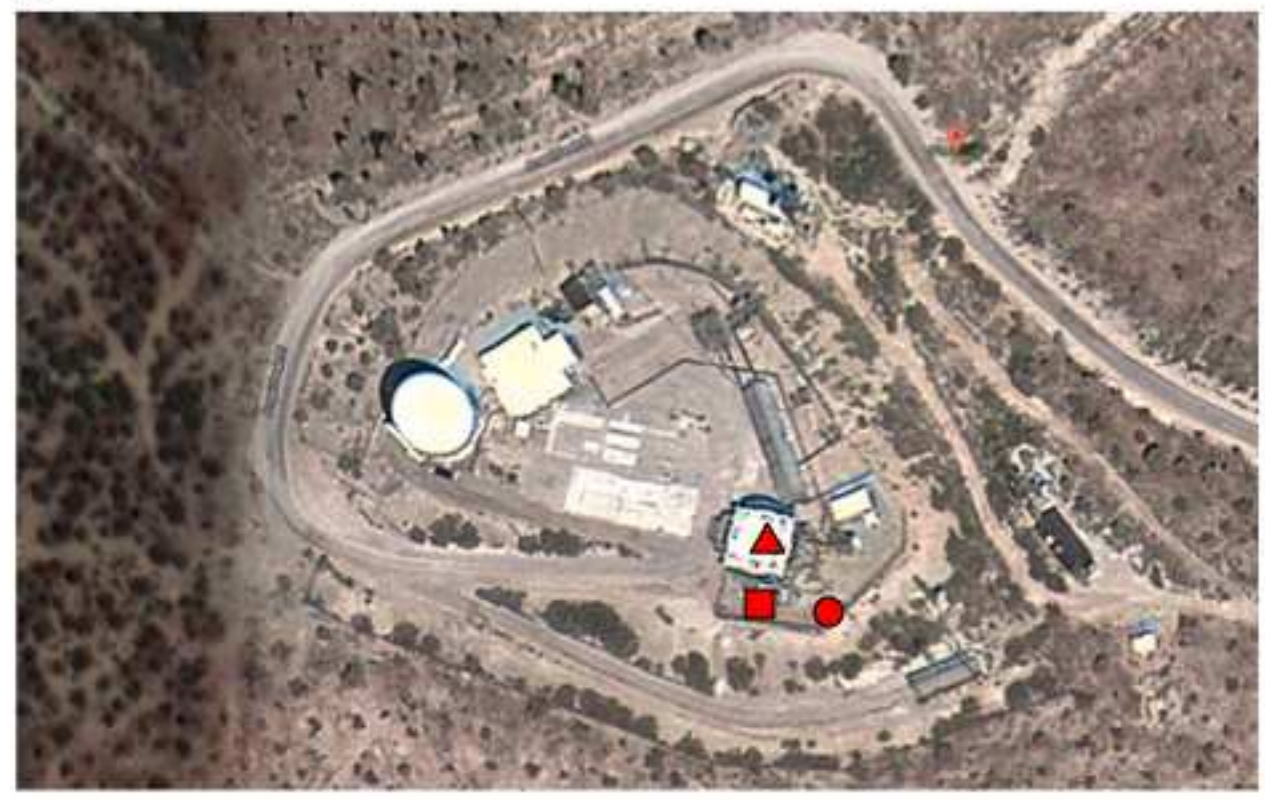

5 Figure 4. Satellite photographs from the U.S. EPA AirNow navigator showing (a) the 6 location of Angel Peak relative to the Las Vegas Valley, and the CC/DAQ ozone 7 monitors (filled circles) and airports (VEF, McCarran International Airport and VGT, 8 North Las Vegas Airport). (b) Locations of TOPAZ (filled square), the in situ monitors 9 (filled triangle), and the met station (filled circle) on the Angel Peak summit. 

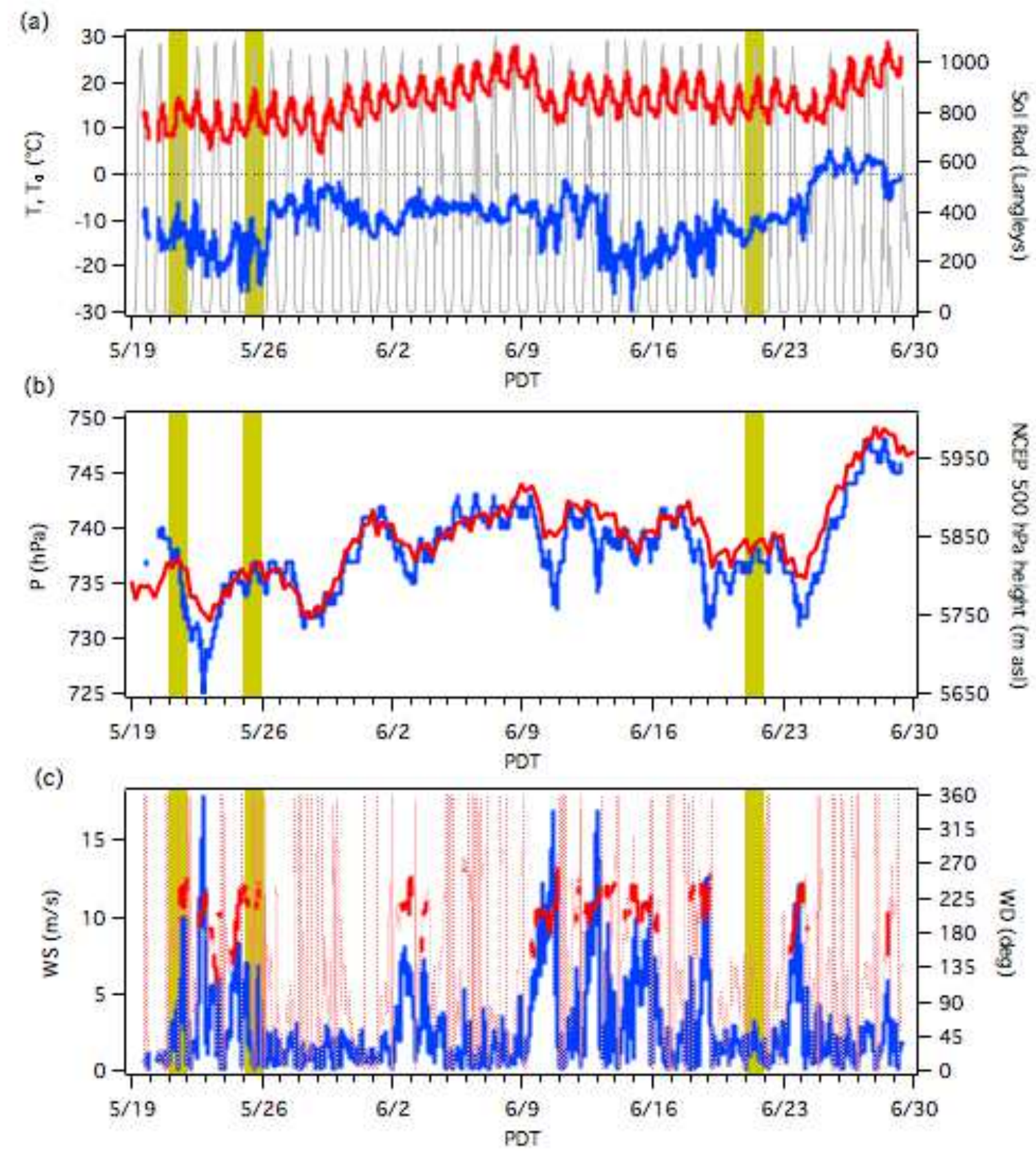

3

4

5

6

7

8

9

10

Figure 5. Time series of (a) solar radiation (gray) with surface temperature (red) and dew point (blue), (b) surface pressure (blue) and NCEP Reanalysis $500 \mathrm{hPa}$ geopotential height (red), and (c) surface wind speed (blue) and direction (dotted red) from Angel Peak. The solid red lines in (c) highlight the wind direction when the speeds were greater than $5 \mathrm{~m} / \mathrm{s}$. The gray bands mark the $\mathrm{O}_{3}$ exceedance days in Clark County. 

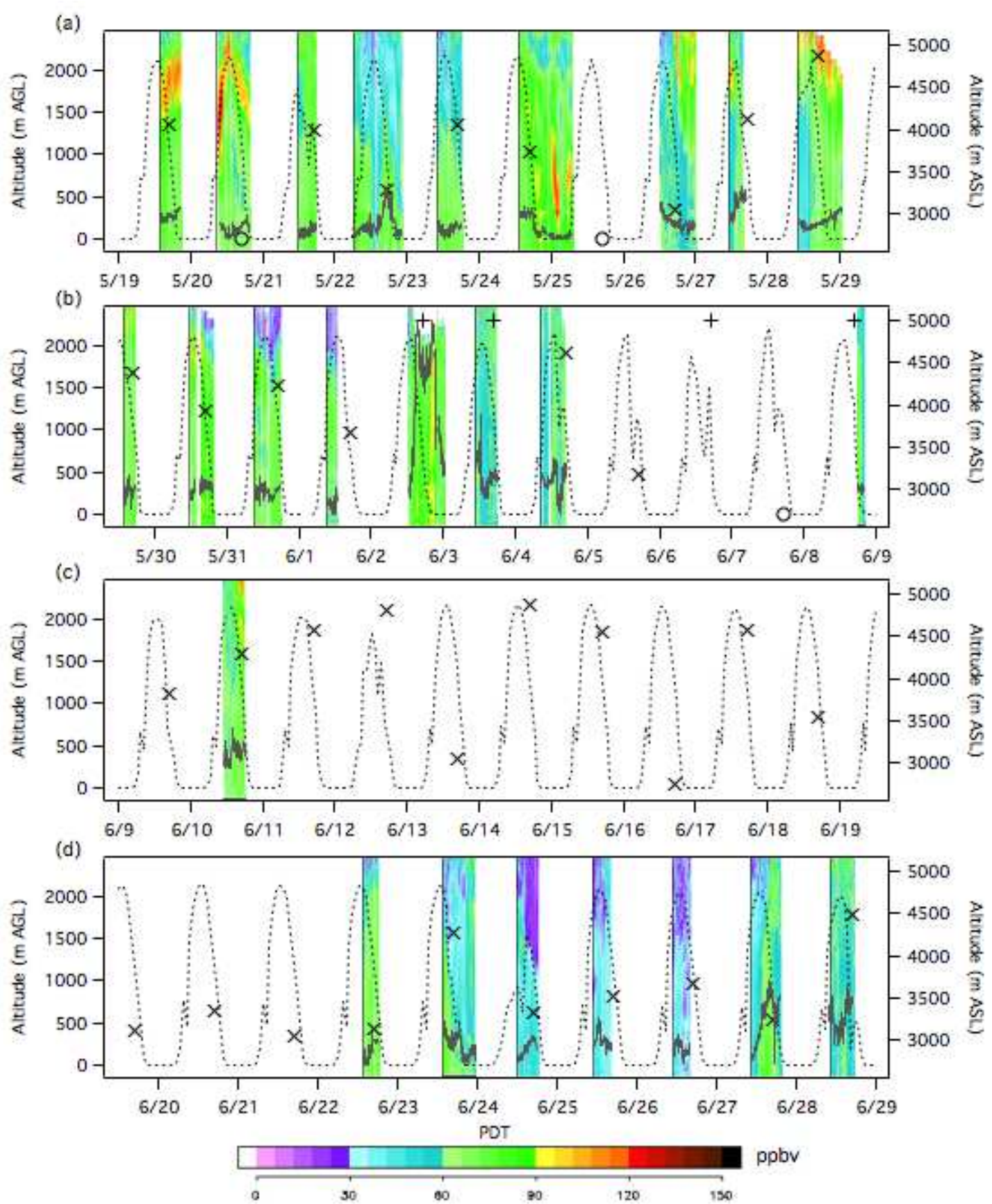

Figure 6. Time-height curtain plots of the ozone concentrations measured by TOPAZ during LVOS. The left axis shows the altitude above the surface of Angel Peak (2.68 km asl) and the right axis the corresponding altitude above mean sea level. The solid black lines show the normalized integrated backscatter from 15 to $2000 \mathrm{~m}$ agl. The " $\mathrm{X}$ " symbols show the mixing heights from the 0000 UT (1700 PDT) McCarran International Airport (VEF) soundings. Mixing heights greater than $5000 \mathrm{~m}$ asl are represented by "+" symbols and missing soundings by "0". The dotted gray curves show the normalized 
(a)

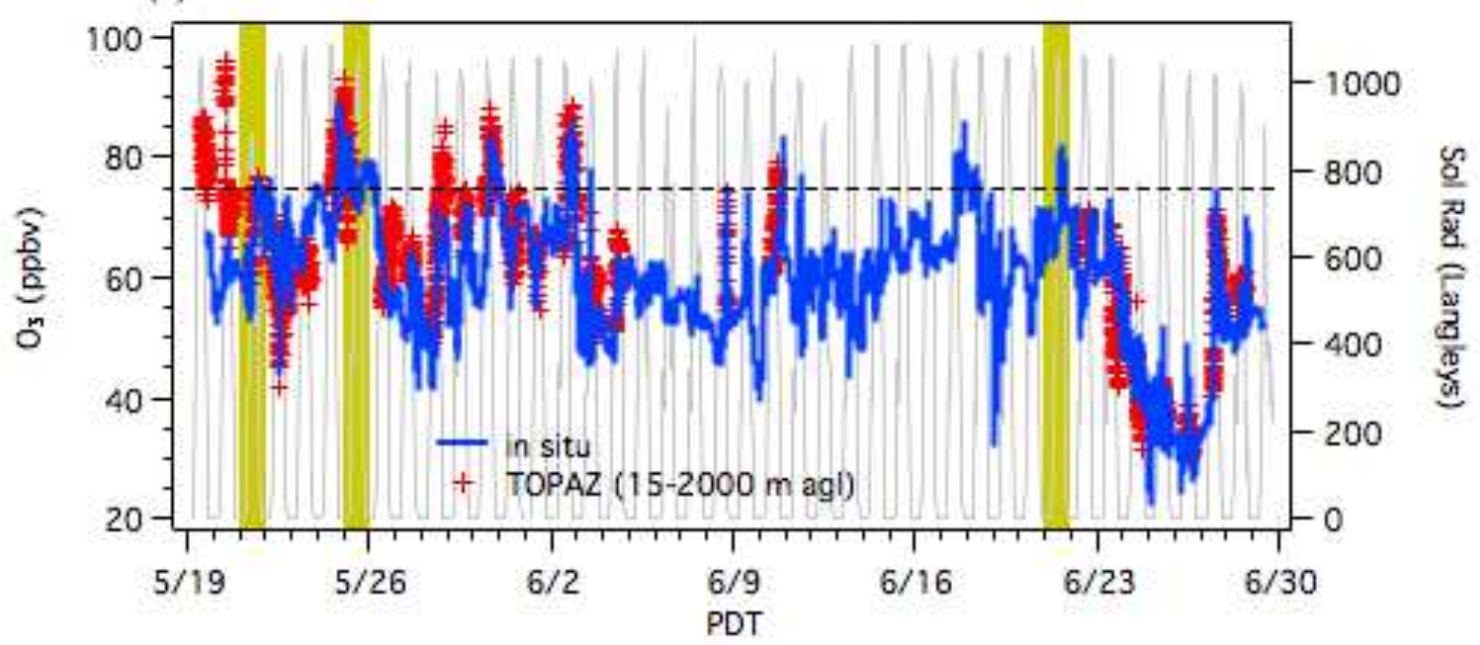

(b)

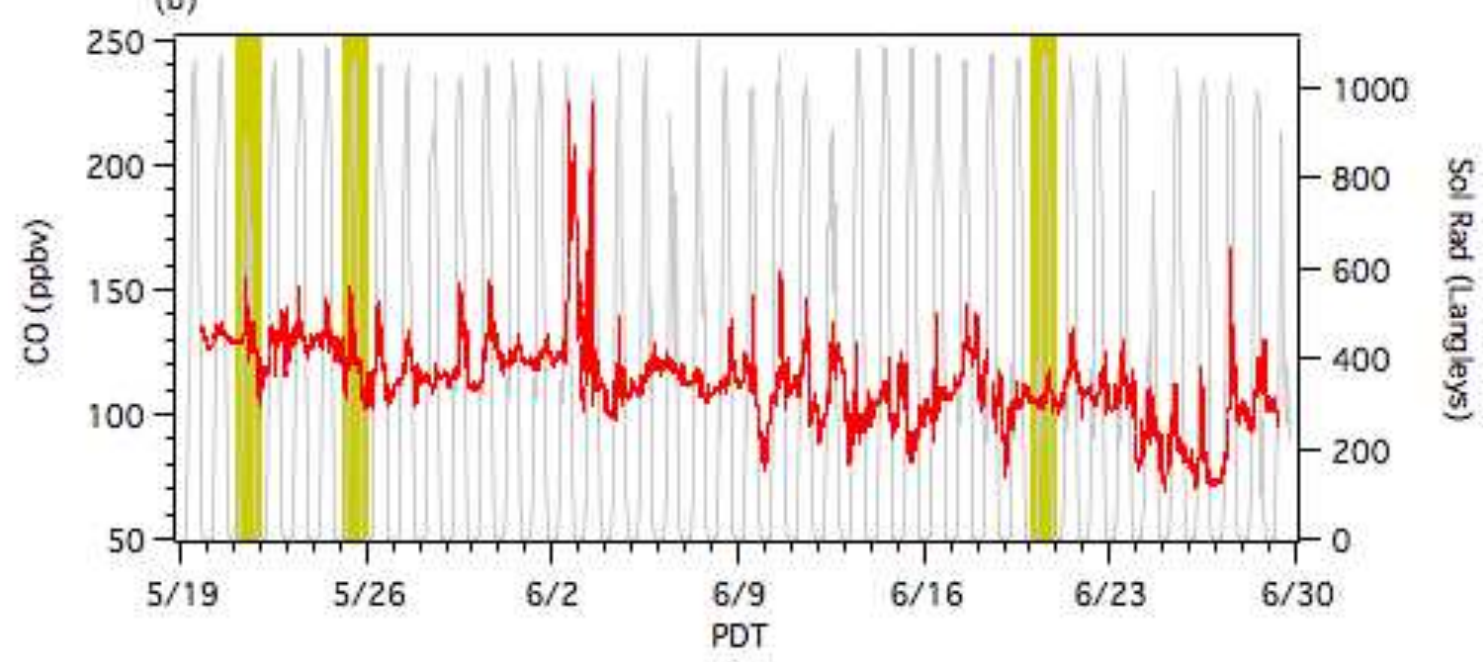

5

7 Figure 7. Time series of 1-min: (a) $\mathrm{O}_{3}$ (blue) and (b) $\mathrm{CO}$ from Angel Peak. The red 8 symbols in (a) show the average 15 to $2000 \mathrm{~m} \mathrm{agl} \mathrm{O}_{3}$ from TOPAZ and the horizontal 9 dashed line marks the 75 ppbv 8-h NAAQS. The gray lines in both plots show the solar 10 radiation measured at the $\mathrm{SMYC}$, and the gray bands mark the $\mathrm{O}_{3}$ exceedance days in 11 Clark County. 

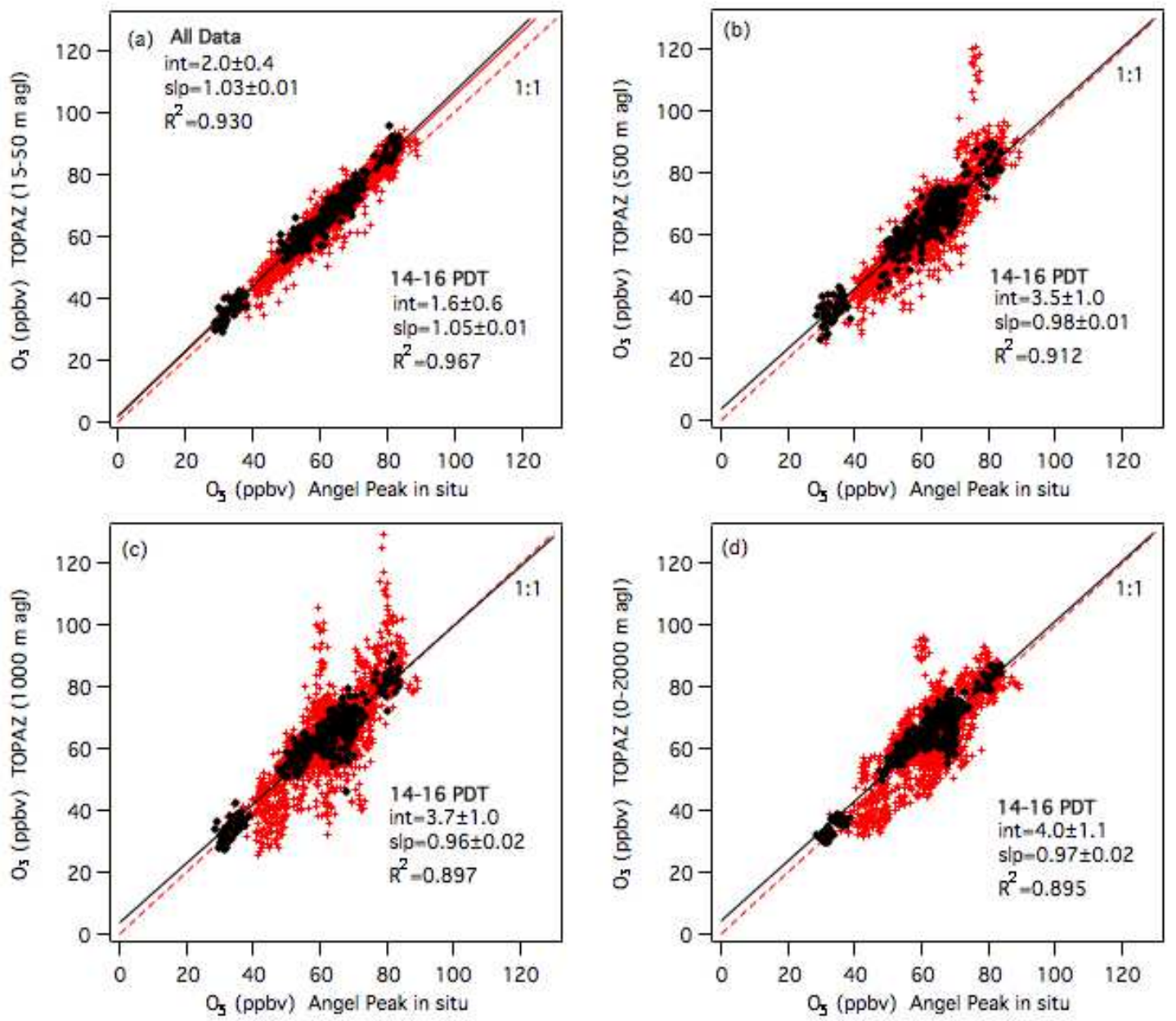

6 Figure 8. Scatter plots showing the correlation between the Angel Peak in situ $\mathrm{O}_{3}$ measurements and the concentrations measured by TOPAZ at (a) $15-50 \mathrm{~m}$ agl, (b) $500 \mathrm{~m}$ agl, (c) $1000 \mathrm{~m}$ agl, and (d) $15-2000 \mathrm{~m}$ agl. The filled black circles show the measurements made when the VEF afternoon soundings show the top of the mixed layer

10 to be at least $2000 \mathrm{~m}$ above the summit of Angel Peak (cf. Figure 6). The 1:1 line is 11 dashed.

12 

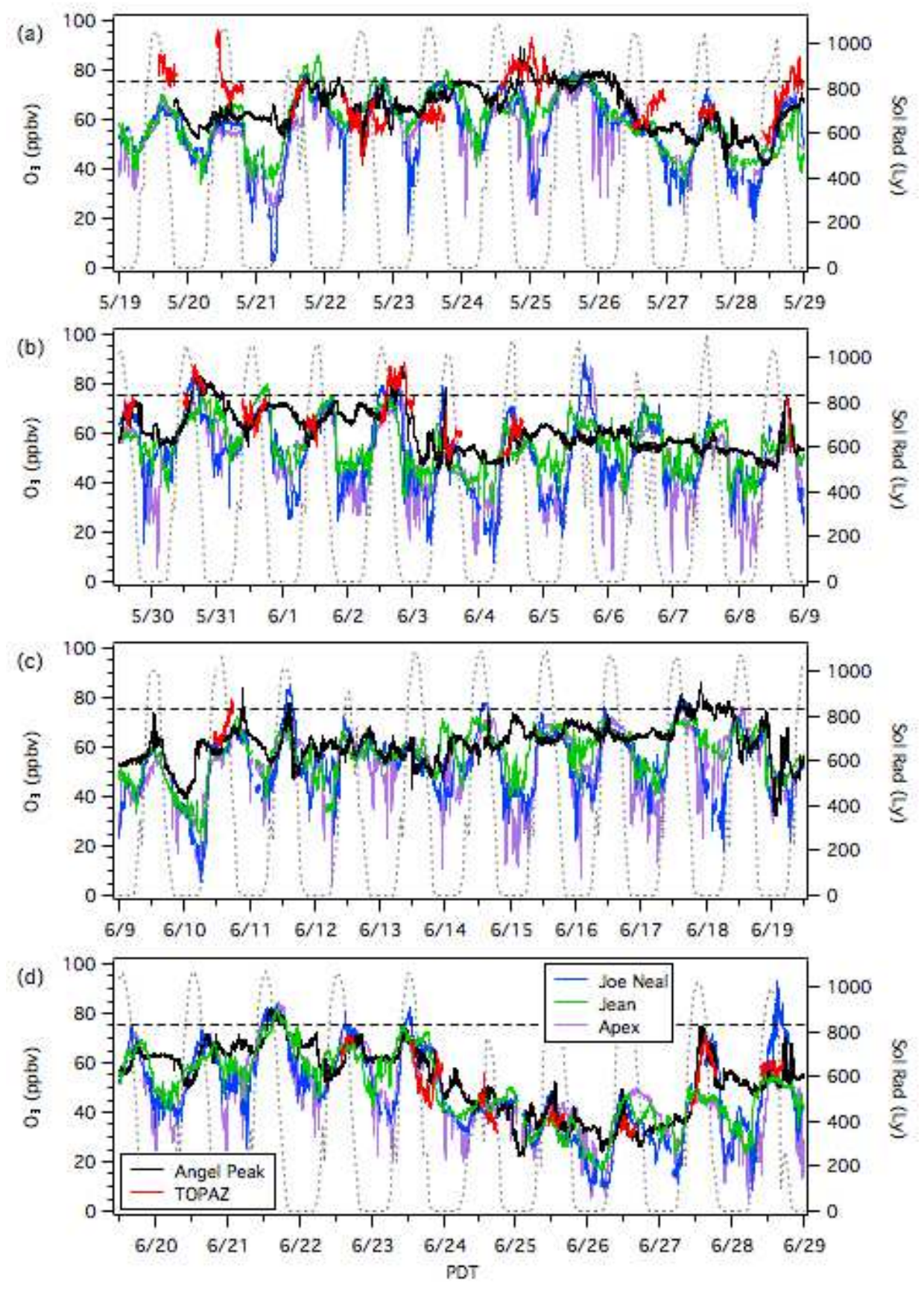

Figure 9. Time series plots of ozone measurements made during LVOS. 1-min in situ measurements from Angel Peak (black), 15-2000 m agl mean from TOPAZ (red), and 5min measurements from the Clark County monitors at Jean (green), Joe Neal (blue), and Apex (purple). The horizontal dashed line marks the current $\mathrm{O}_{3}$ NAAQS and the dotted curves show the solar radiation measured at the SMYC. 

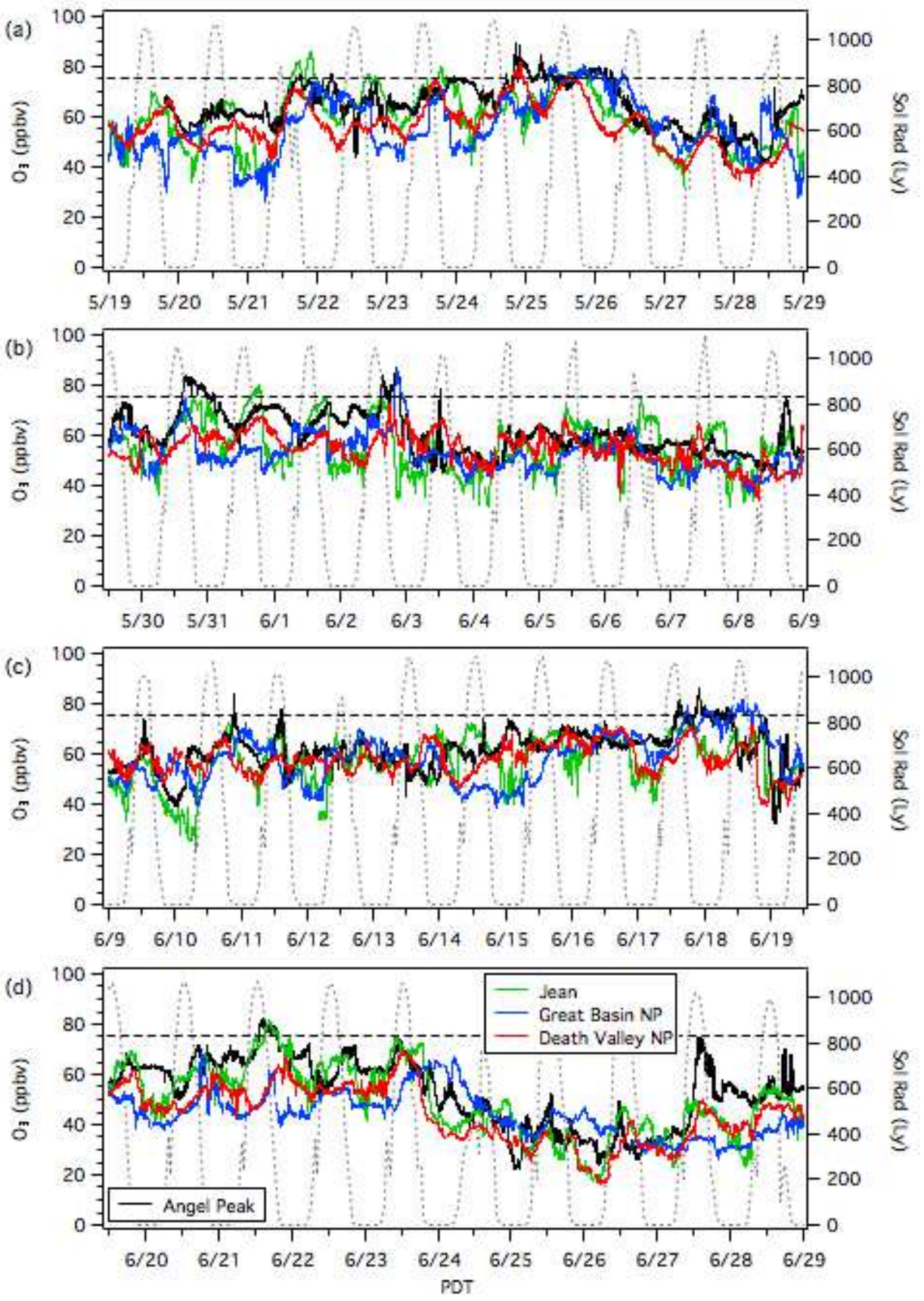

Figure 10. Time series plots of ozone measurements made during LVOS. 1-min in situ measurements from Angel Peak (black), and 5-min measurements from the Clark County monitor at Jean (green), and the U.S. National Park Service monitors at Great Basin NP 8 (blue) and Death Valley NP (red). The horizontal dashed line marks the $2008 \mathrm{O}_{3} \mathrm{NAAQS}$ 9 and the dotted curves show the solar radiation measured at the SMYC. 
(a)

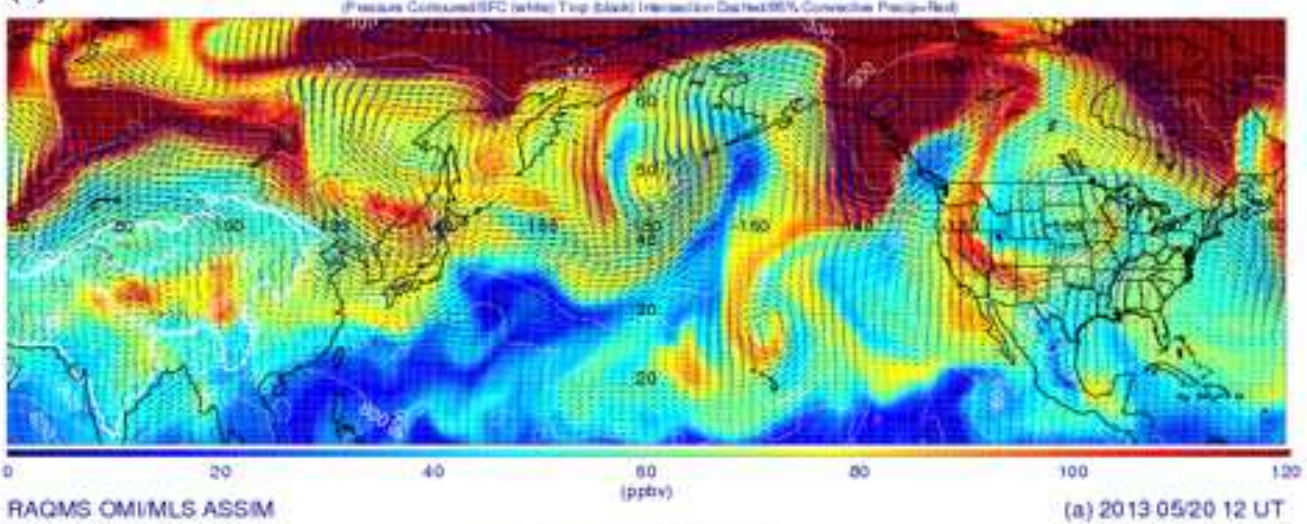

(b)

310K O, 12220130524

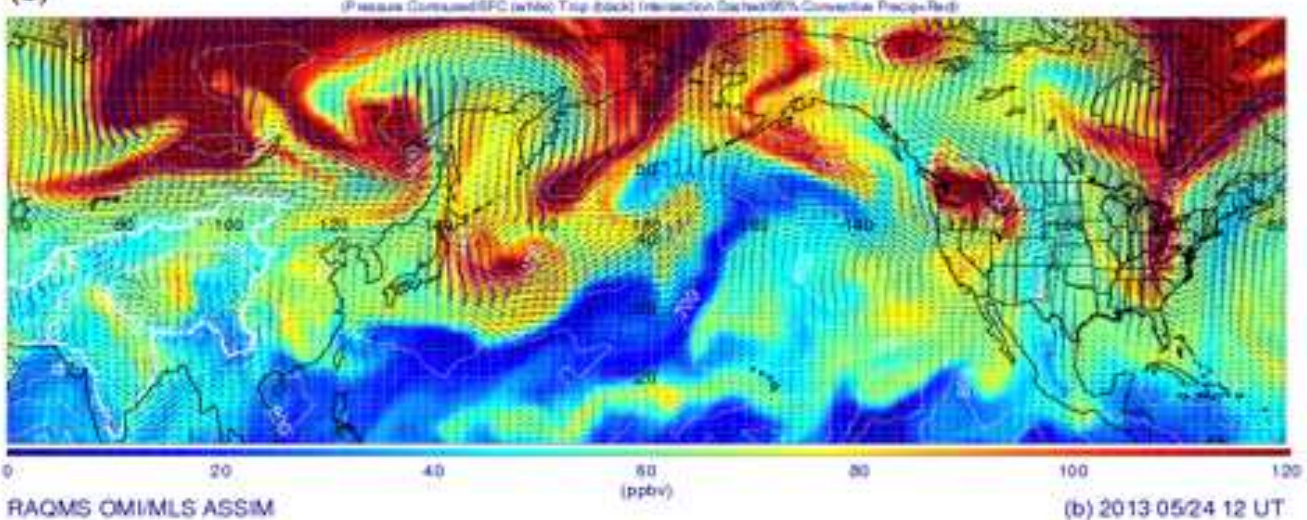

(c)

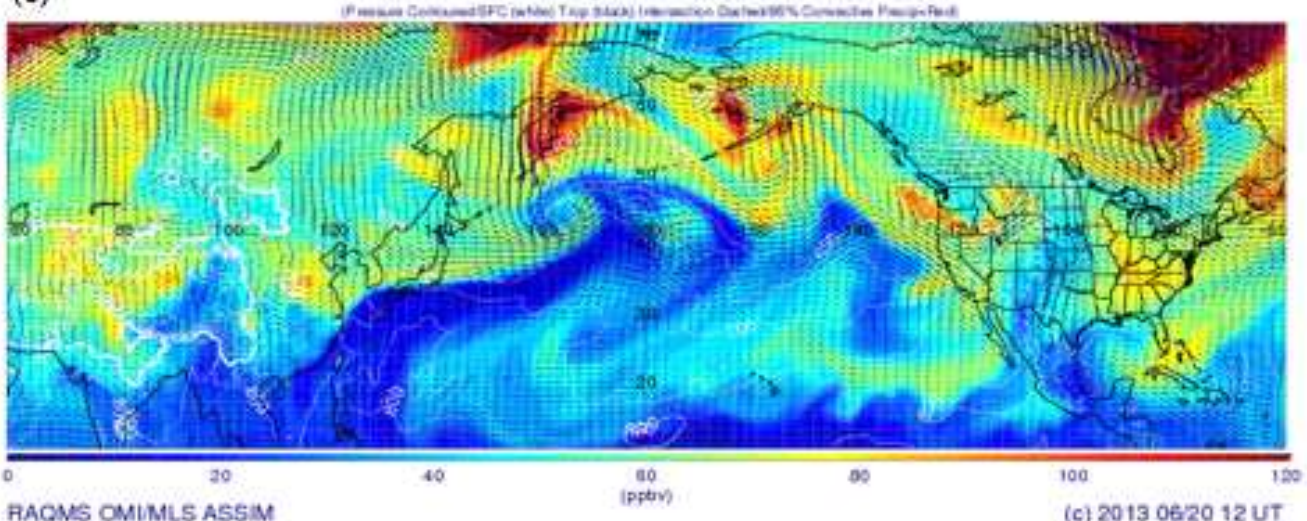

(c) 2013062012 UT 

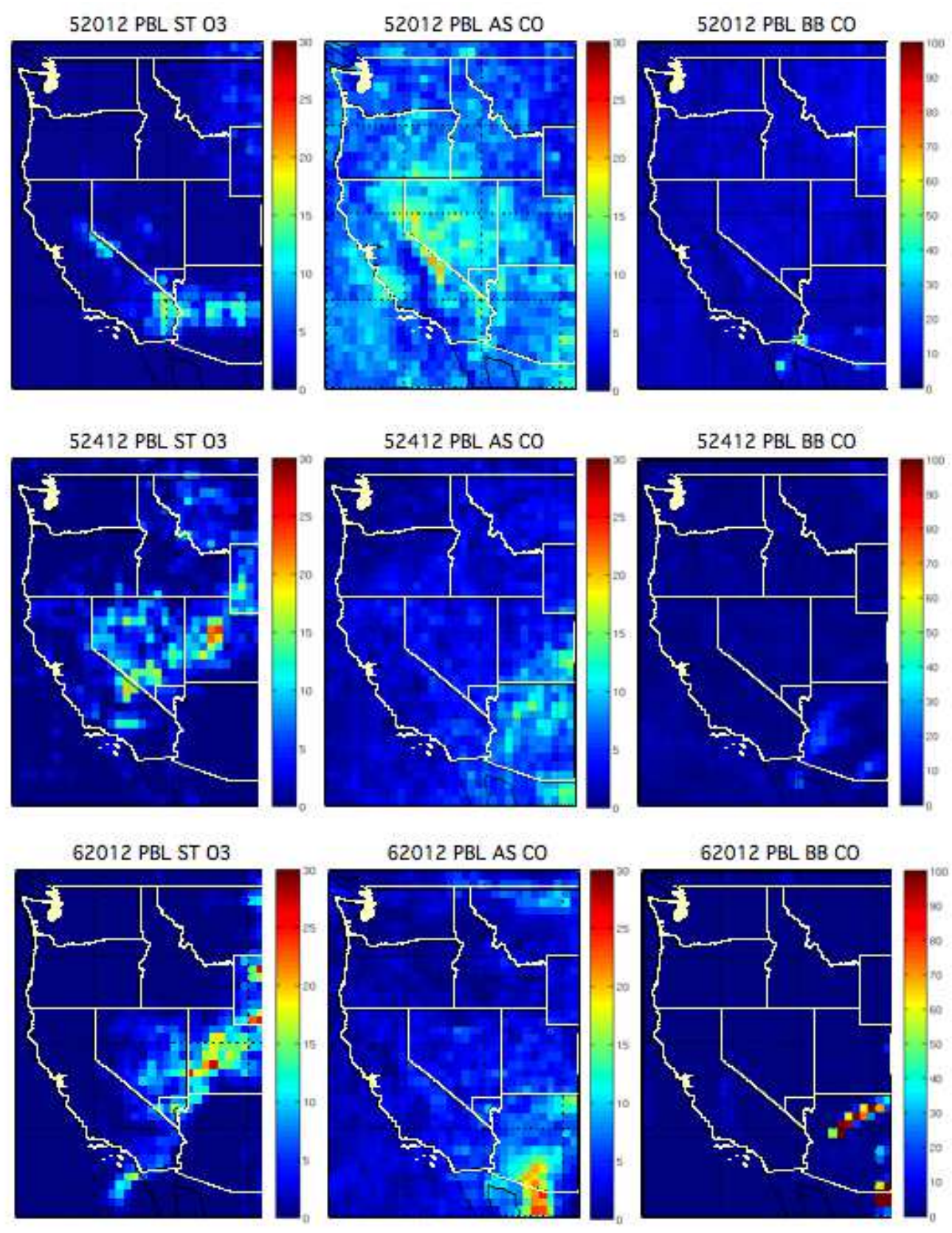

4 Figure 12. FLEXPART source mode distributions of the stratospheric $\mathrm{O}_{3}$ (left), Asian 5 pollution $\mathrm{CO}$ (center), and biomass burning $\mathrm{CO}$ (right) tracers below $1.5 \mathrm{~km}$ asl at 1200 6 UT on May 20 (top), May 24 (middle), and June 20 (bottom) 2013. The color bars show 7 the tracer concentrations in ppbv. 
1

2

3

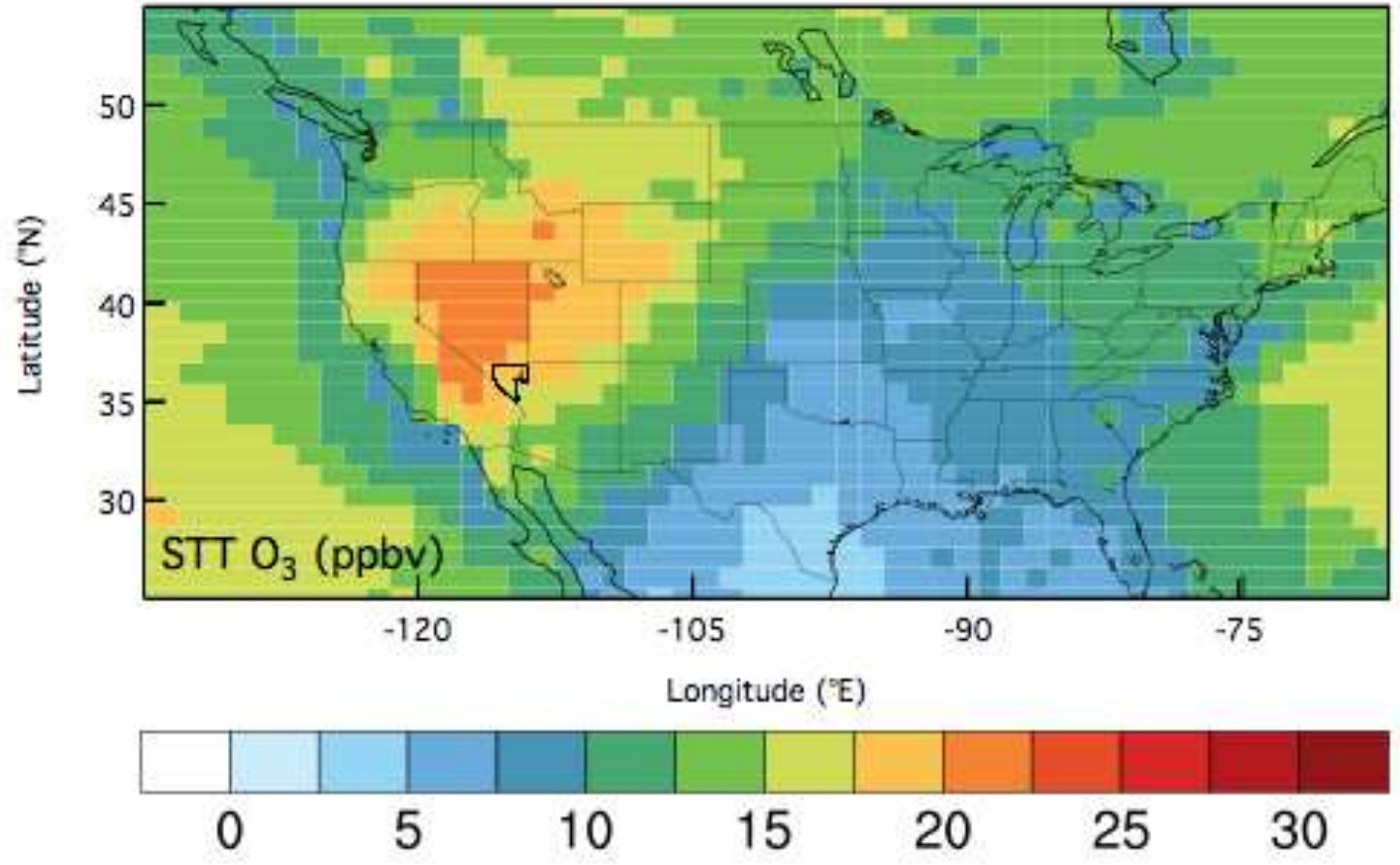

Figure 13. NOAA GFDL AM3 model median contribution of STT to MDA8 surface $\mathrm{O}_{3}$ during May and June of 2013. The resolution is $100 \mathrm{~km} \times 100 \mathrm{~km}$. Clark County, NV is outlined in black.

10

11 

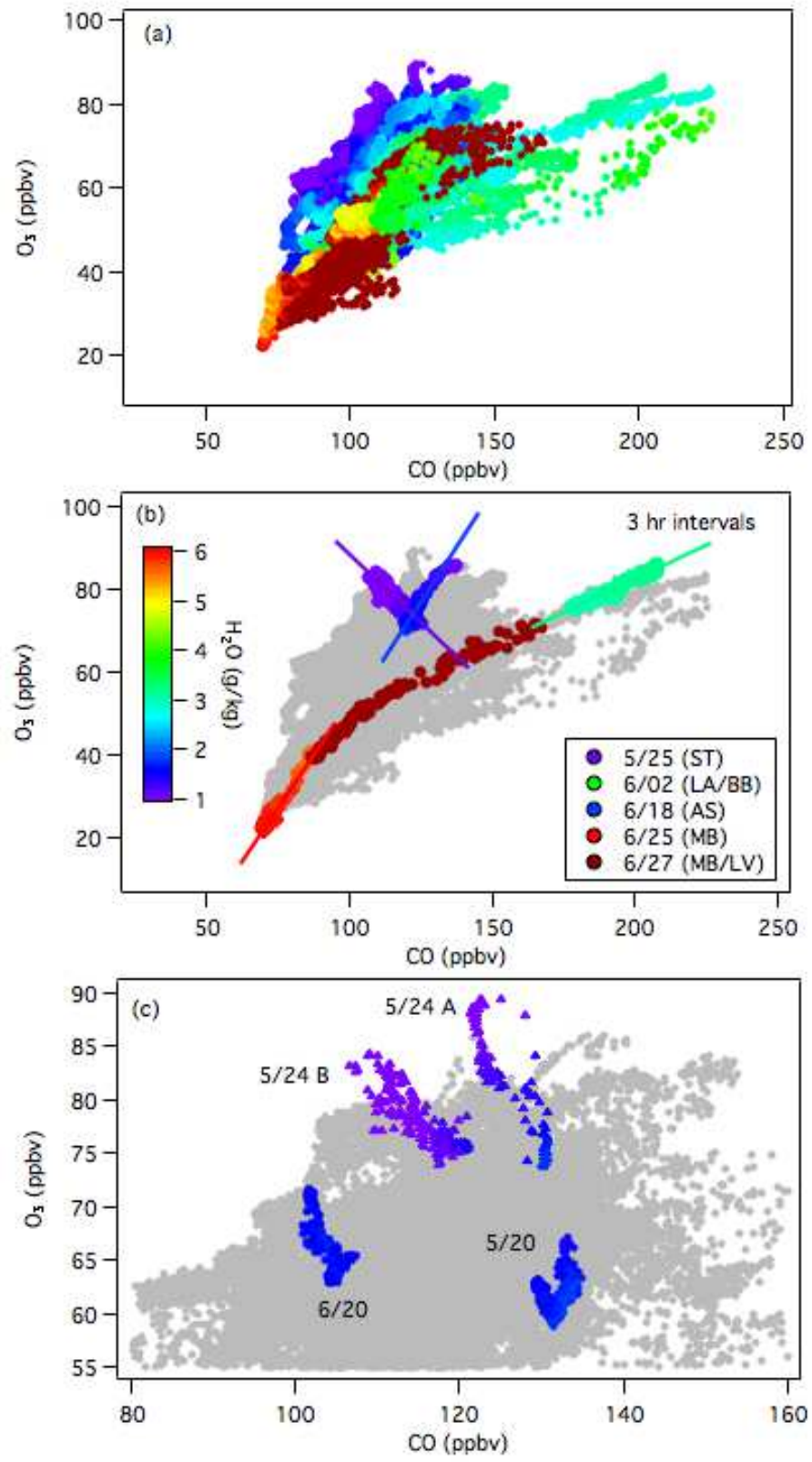

4
Figure 14. Scatter plots of the 1-min in situ $\mathrm{O}_{3}$ and $\mathrm{CO}$ measurements from Angel Peak during LVOS color-coded by specific humidity. (a) All data from the campaign. (b) Isolated measurements from five different 3-hour intervals showing mixing lines attributed to the influence od stratospheric air (ST), biomass burning and urban pollution from the LA Basin, (LA/BB), transport from Asia (AS), subtropical marine boundary layer air (MB), and local pollution from the Las Vegas Valley (LV). (c) Characteristic mixing lines associated with the mixing of boundary layer and UT/LS air. 

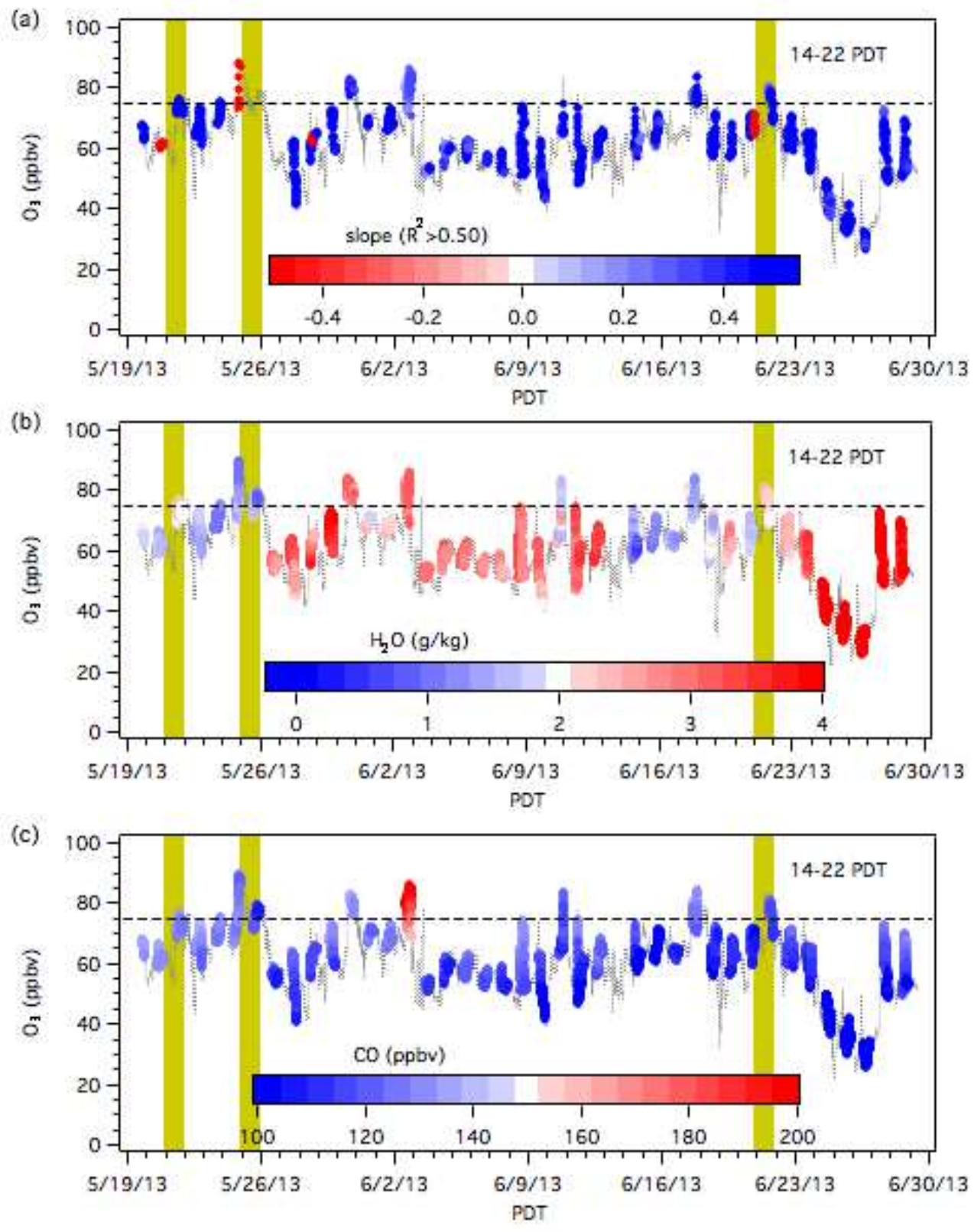

4

Figure 15. Time series of the in situ $\mathrm{O}_{3}$ at Angel Peak color-coded by (a) the slope of the regression with $\mathrm{CO}\left(\mathrm{R}^{2}>0.5\right.$ only), (b) specific humidity, and (c) $\mathrm{CO}$ concentrations. The horizontal dashed line indicates the 75 ppbv 8-h NAAQS. The yellow bands mark the three exceedance days in Clark County. 

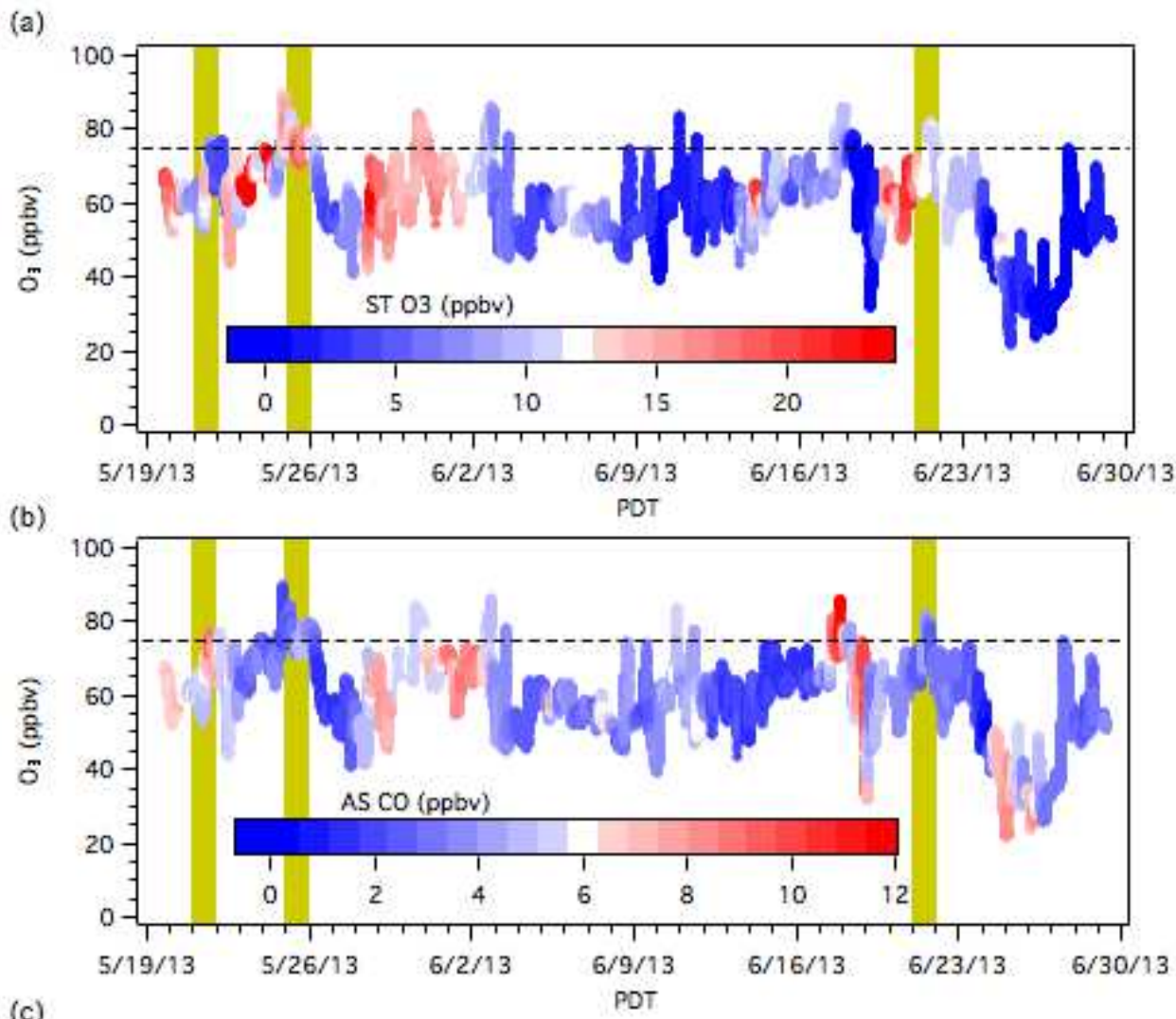

(c)

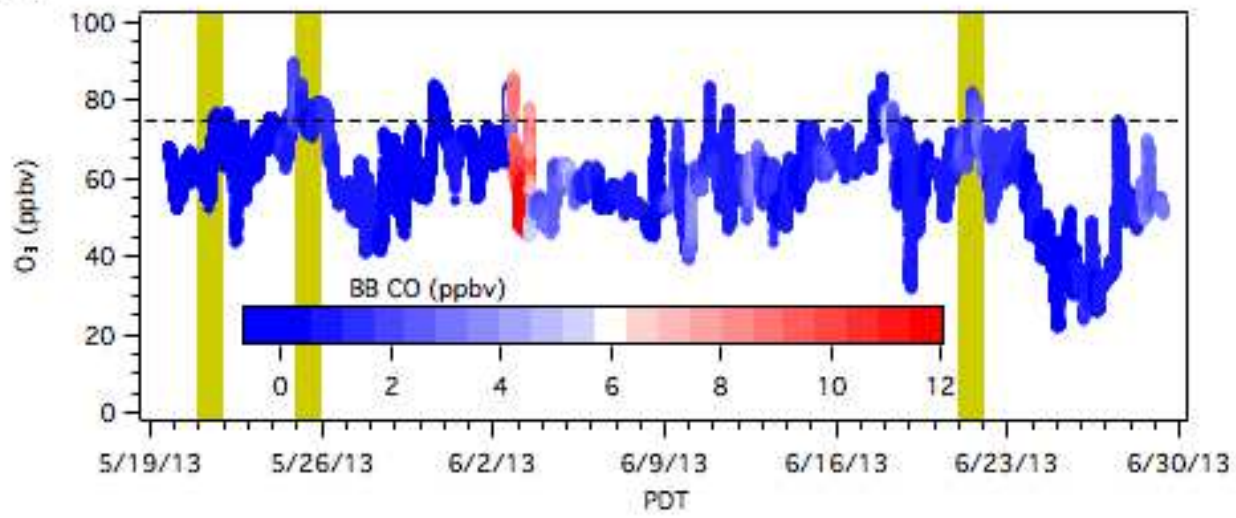

4

10

11
Figure 16. In situ $\mathrm{O}_{3}$ and $\mathrm{CO}$ measurements from Angel Peak color-coded by (a) stratospheric $\mathrm{O}_{3}$, (b) Asian transport $\mathrm{CO}$, and (c) biomass burning $\mathrm{CO}$ tracers from the FLEXPART back trajectories originating from $1000 \mathrm{~m}$ asl. The horizontal dashed line indicates the 75 ppbv 8-h NAAQS. The yellow bands mark the three exceedance days in Clark County. 

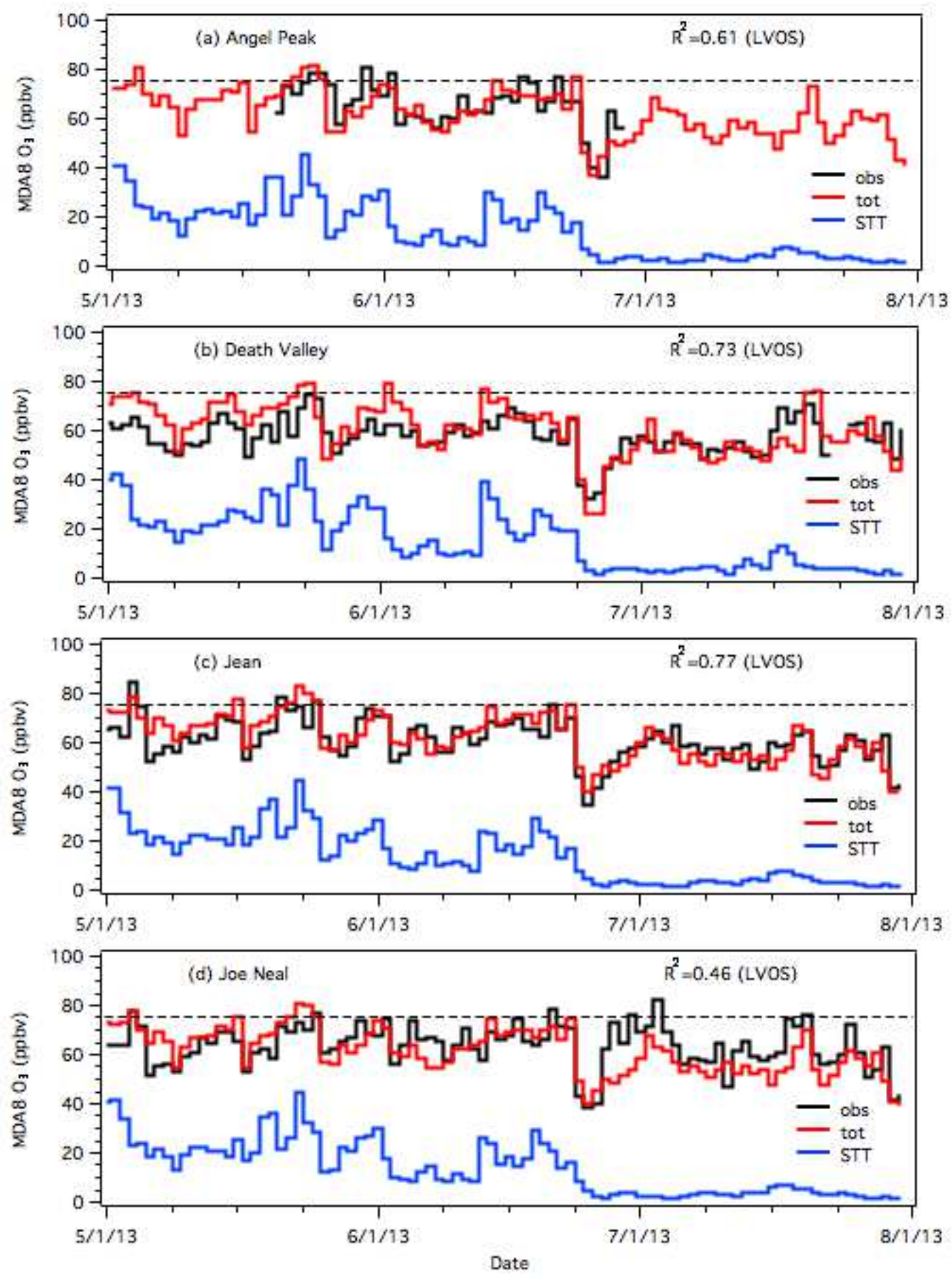

5 Figure 17. Time series comparing the AM3 total MDA8 ozone (red) calculated for (a) 6 Angel Peak, (b) Death Valley, (c) Jean, and (d) Joe Neal to the measured values (black).

7 The blue traces isolate the STT contribution to the calculated totals. The correlation

8 coefficients are derived from linear regression fits using the data from May 19 to June 28

9 (LVOS) only. 

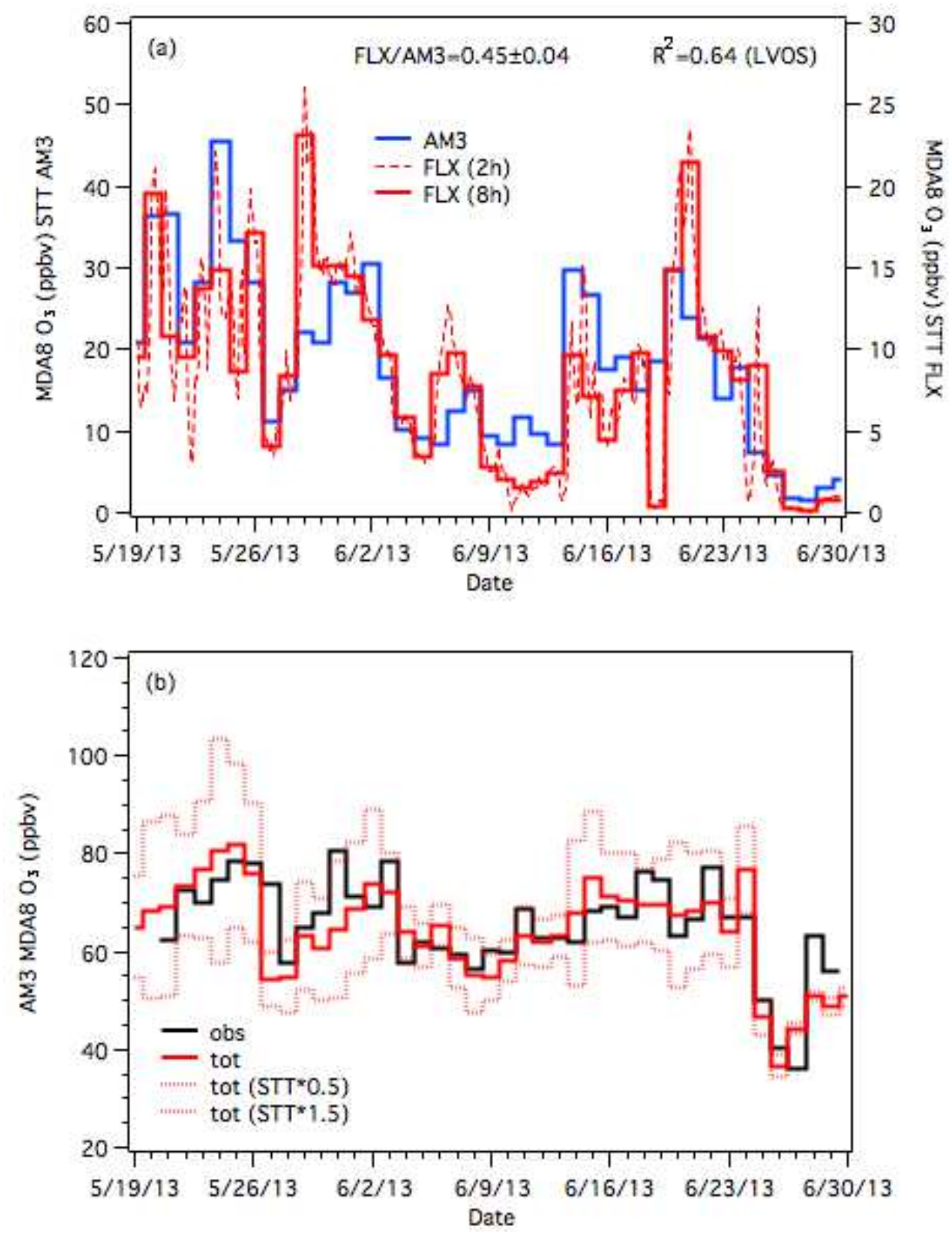

Figure 18. (a) Time series comparing the AM3 (blue) and FLEXPART (red) STT ozone calculated for Angel Peak during LVOS. The model results are well correlated but differ by about a factor of two (note the different vertical scales). (b) Angel Peak MDA8 observations with the calculated AM3 STT contribution (solid red line) and the AM3 STT contribution scaled by $\pm 50 \%$ (dotted red lines). 